\title{
Review of Prodromal Symptoms In Parkinson's Disease Detected By MRI, EEG And Microbiome
}

\author{
Short title: Review Of Prodromal Symptoms In Parkinson's Disease
}

Isabel Cristina Echeverri $\mathbf{O}^{\mathbf{1}}$,

Maria de la Iglesia Vayá ${ }^{2}$,

Jose Mateo Molina ${ }^{3}$,

Francia Restrepo de Mejia ${ }^{4}$

, Belarmino Segura Giraldo 5

\begin{abstract}
${ }^{\mathbf{1}}$ Group of automática, group of Neuroaprendizaje ${ }^{2}$ Joint Research Unit of Biomedical Imaging, Valencia, Spain ${ }^{3}$ Centre for Biomaterials and Tissue Engineering Universitat Politècnica de València, Valencia, Spain ${ }^{4}$ group of Neuroaprendizaje Universidad Autónoma de Manizales, Manizales, Colombia ${ }^{5}$ PCM Computational Applications, Universidad Nacional de Colombia, Manizales, Colombia
\end{abstract}

\section{Abstract:}

\section{Context:}

Parkinson's disease (PD) is catalogued as a disorder that causes motor symptoms; the evidence of literature shows the PD starts with non-motor signs, which can be detected in prodromal phases. These previous phases can be analyzed and studied through magnetic resonance images (MRI), electroencephalography (EEG) and microbiome.

Objective: To systematically review the areas of the brain and brain-gut axis which affect in early Parkinson's disease that can possibly be visualized and analyzed by MRI, EEG and the microbiome.

Evidence acquisition: Pubmed and Embase databases were used until July 30, 2018 as to search for early Parkinson's disease at its earliest non-motor symptoms stage by using MRI, EEG, and microbiome. The search was performed according to the requirements of a systematic review. In order to identify reports, we evaluated them following the Quality Assessment of Diagnostic Accuracy Studies (QUADAS-2) criteria.

Evidence synthesis: MRI and EEG have provided the advances to find features for PD over the last decade. Those techniques identify motor symptoms on substantia nigra where the patient shows a dopamine deficiency. However, over recent years, researchers have found that PD has prodromal phases, that is, PD is not simply a neurodegenerative disorder characterized by the dysfunction of dopaminergic. Thus, high field MRI, event-related potential (ERP) and microbiota data shows a significant change on the brain cortex, white and grey matter, the extrapyramidal system, brain signals and the gut.

Conclusion: The structural MRI is a useful technique in detecting the stages of motor symptoms on the substantia nigra in patients with PD. The use of magnetic resonance as an early detector requires a high magnetic field, as to identify the areas which diagnose that the patient could be in the premotor stages. On the other hand, EEG performed well in detecting PD features. Furthermore, microbiome sequencing might include the classification of bacterial families that could help to detect PD in its prodromal phase. Thus, the combination of all these techniques can support the possibility of diagnosing PD in its very early stages.

Key words: Parkinson disease, event-related potentials, electroencephalograpjy, magnetic resonance image, microbiome, non-motor symptoms. 


\section{Introduction}

Parkinson's disease is commonly associated with the degeneration of substantia nigra, where the dopamine cells die and then, motor symptoms appear in the patient. However, researchers have been questioning the evolution of PD before the motor symptoms manifest themselves (Kelly Del Tredici, Udo Rüb, Rob A.I de Vos, Jürgen R.E. Bohl, 2002) and how to obtain an indicator to evaluate these prodromal conditions of the disease.

Therefore, in the literature many Scientifics have been reported this clinic-pathological concept of the PD that is questioned by numerous positions of evidence: Firstly, it has been noted that before motor symptoms manifested in the patient, $40 \%$ of the dopaminergic cell neurons in the nervous system (NS) are lost (Qiao, Shi, Jiang, Gao, \& Niu, 2017). Secondly, Braak and collogues have suggested that neurodegeneration of PD is initiated in the lower brainstem and anterior olfactory structures before ascending to the basal ganglia (Barber, Klein, Mackay, \& Hu, 2017) (Hammclement \& Sandmann-keil, 2002). Thirdly, a prominent hypothesis concerning the neuropathological progression of PD suggests that the Lewy body deposition originates in the enteric and peripheral nervous system, before appearing in the brain stem and then progressing to the midbrain, forebrain and neocortex (Ziegler et al., 2013). Indeed, constipation, olfactory loss, depression and sleep disorder have been strongly reported to go along with a significantly increased risk in developing PD (Mahlknecht, Seppi, \& Poewe, 2015).

In this context, the studies of image-signal brain are becoming more relevant to observe and find the characteristics of PD. The magnetic resonance image (MRI) is a common technique that includes structural magnetic resonance imaging, functional MRI (fMRI), Diffusion Tensor Imaging (DTI), and among others; their features are quantitative which reflects the incidence of the disease and it has the capacity of showing electrical brain activity that can be indicative of PD. Moreover, these techniques have offered several features that can help in identifying the disease process (Pyatigorskaya, Gallea, Garcia-lorenzo, \& Vidailhet, 2014). EEG might also be a clue in finding early alterations through ERP such as emotional, olfactory and sleeping disorders, all of which are events associated with the non-motor symptoms of Parkinson's disease.

In recent years, microbiome has taken an important role in discovering alternative features within the brain-gut axis which could be related to PD (Caputi \& Giron, 2018). Since, studies have reported that the enteric nervous system (ENS) is able to communicate with the central nervous system (CNS) through the vagal nerve. Therefore, this brain-gut axis has brought a hypothesis related to neurodegeneration diseases, such as Parkinson's disease (Gershanik, 2017).

The advantage of MRI, ERP and microbiome are that they are non-invasive techniques which are not going to accelerate nor yield other symptoms in the patient; in fact, they are tremendous evidence in determining clue features of PD. Moreover, these techniques are relatively economics when it comes to conducting clinical or research test.

In this systematical review, we evaluated the evidences of obtaining by MRI, EEG, and microbiome the early Parkinson's disease, particularly focused on non-motor symptoms, with the aim of assessing such techniques as an early indicator to characterize the non-motor symptoms. We required detecting studies with the following criteria: MRI in cortical thickness, white and grey matter, extrapyramidal system, EEG recording with event related potentials (ERP), and evidences of PD in microbiome in order to obtain a set of prodromal biomarkers of the disease.

\section{Literature systematic review}


This present review is aimed to show how the non-motor symptoms can manifest through the brain signals, MRI and microbiome; with the aim of providing more information about this issues and highlight future work. This systematic review used the phase proposed in The QUADAS-2 guidelines, which were used to asses study quality of all the chose publications (Penny F.Whiting; Anne W.S Rutjes; Marie E. Westwood; Susan Mallett; Jonathan J. Deeks; Jahannes B. Reitsma; Mariska M.G. Leeflang; Jonathan A.C. Sterne; Patrick M.M. Bossuyt; and the group of quadas-2, 2011)

\subsection{Research question}

A systematic review has a fundamental knowledge with questions that scientific production, as such as journals, conferences proceedings in order to obtain the status of non-motor symptoms of Parkinon's disease techniques of ERP, MRI and microbiome. All these ideas led us to several fundamental research question

- Can MRI techniques find features of Parkinson's disease in early stages?

- Can EEG and event-related potential provide features of Parkinson's disease in early stages?

- Can the microbiome data show features of early Parkinson's disease?

\subsection{Data sources}

The automatic search performed in Embase and Pubmed databases. After this search, a detailed analysis obtained papers in order to consider the relevance of the studies and avoid repetitions.

The search for information considered authors, with the aim of obtaining a list of articles which explain the features of the non-motor symptoms of Parkinson's disease.

The terms chosen for this search were:

- Parkinson disease.

- Magnetic Resonance Image.

- Event-related potential.

- Microbiome.

According with the terms mention above, we made the search string which are complemented with the identifiers "OR" and "AND" to improve the results. The search process was limited to papers published in English and in journals or proceedings between 2009 and 2019. (In the supplementary document can visualize the whole search string that we use that referred to the questions we formulated in the research questions). 


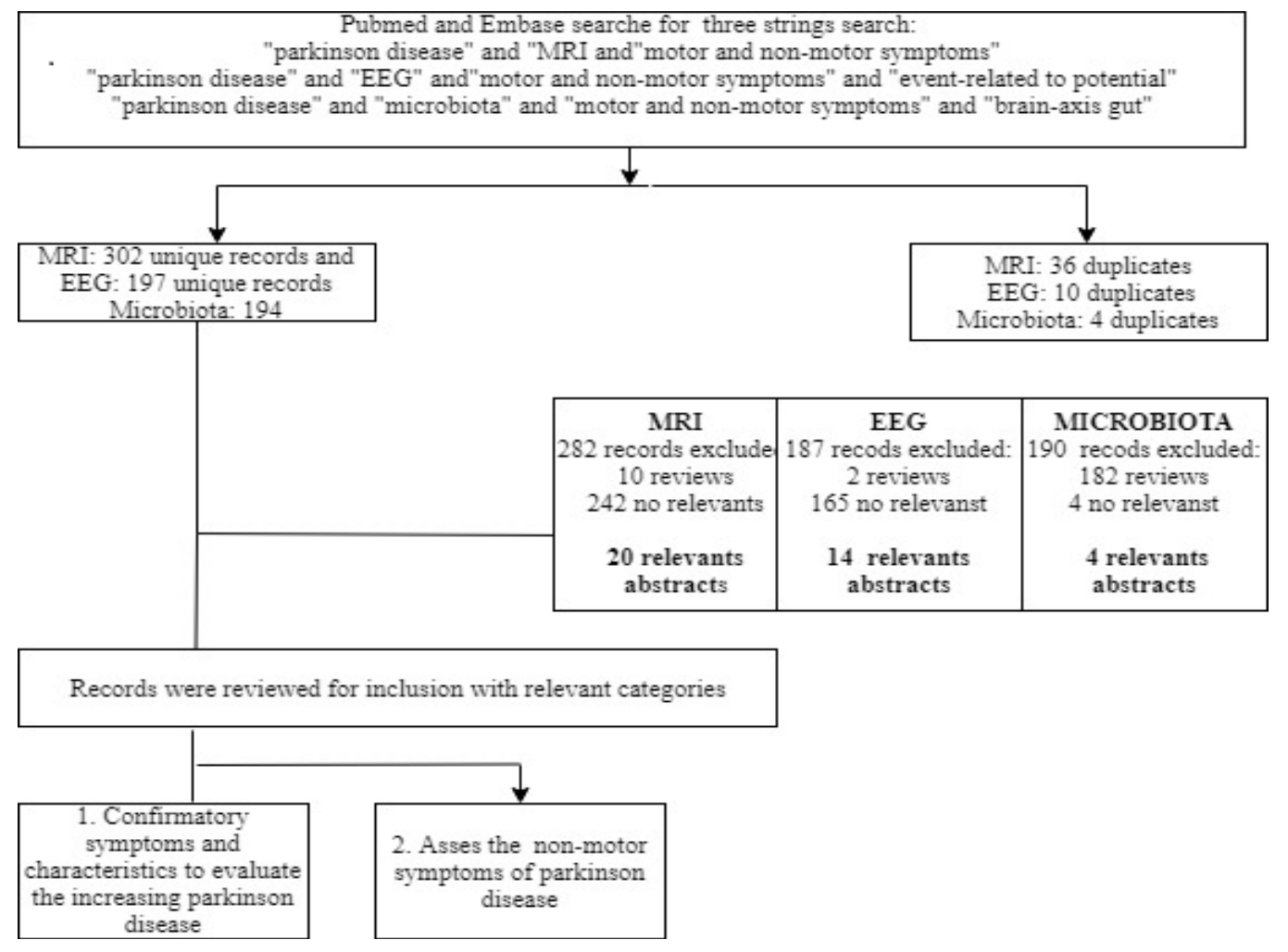

Figure 1 Study selection. The most recent search of articles to be included in this review

\subsection{Criteria for selecting a study}

The studies obtained from the databases were selected for a deep insight under the following criteria:

- Studies that show MRI, EEG and microbiome processing in Parkinson disease.

- Studies that describe where PD begins before motor symptoms manifest.

- Studies that analyze diverse parts of the brain and compare the PD with situations such as depression, REM sleep phase disorders or olfactory alteration disorders.

- Studies that investigate the microbiome and the gut in PD.

- Some reviews that delve into the different types of MRI to evaluate the PD.

In tables 1, 2 and 3 we show the studies that used MRI, EEG and microbiome to assess PD with their respective evaluation by mean of QUADAS-2 methodology.

\subsection{Data extraction on the accuracy of the studies}

Strategies used to assess the data extraction included the QUADAS-2 sheet editor (Microsoft Excel $^{\mathrm{TM}}$ ). The relevant information about MRI, EEG and microbiome was registered on this sheet, analyzing the zones and signals of the brain that are involved in PD. This information is presented in tables 1,2 and 3. We carefully analyzed each study with the purpose of answering the questions that we had set out at the start.

The 88 articles obtained by the search on the Pubmed and Embase database were chosen in the preliminary reading as a reference; the steps taken for systematic review are described in the figure 1. As a plus, the articles were classified by year and their results are shown in the figure 2 . 


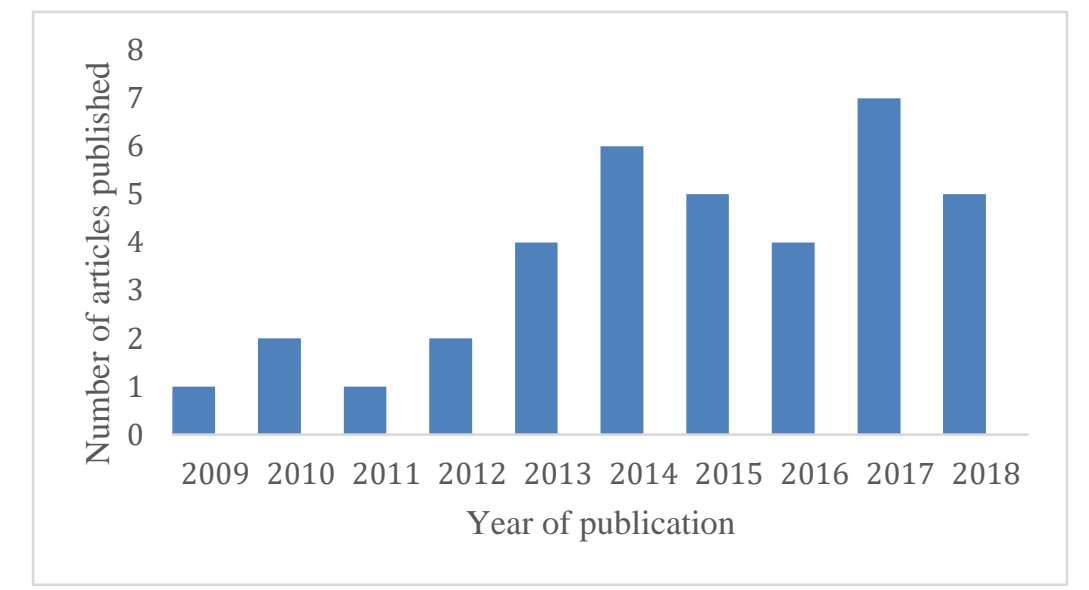

Figure 2 Number the articles published in Pubmed and Embase with respect of the year

\section{Methodological quality}

After reading the 88 articles, 38 highly reliable articles were chosen for the systematical review as they were found in high-impact international journals. In the reading, the following parts of the articles were taken into account:

- Title

- Abstract

- Introduction

- Results

- Conclusions

Once the reading finished, the quality and the risk of bias of the articles was established and defined by the details of QUADAS-2. The tool composes of the following 4 domains: patient selection, index test, reference test, flow and timing. Each domain was evaluated in terms of risk of bias and the first 3 domains were also evaluated in terms of applicability. The quality of the evidence was recapitulated by describing the 38 articles that were considered in having a high/low/unclear risk of bias and in terms of applicability.

\subsection{Evidence synthesis}

A total of 38 articles evaluated the prodromal symptoms in Parkinson's disease. These studies were divided into 3 different tables, with the intention to find pertinent characteristics, since the PD is being diagnosis as premotor symptoms of the pathological process. Braak et al. (2003), say that Parkinson's disease begins when an external agent entering into the central nervous system by the bias nose or the gastrointestinal system. Therefore, this systematic review is focused on the synthesis of the studies in prodromal symptoms in 3 great techniques: MRI, event-related potential and microbiome (tables 4 , 5,6 visualize the studies used).

Each technique provides information corresponding to the prodomical symptoms of PD. In MRI 20 articles were chosen and 14 and 4 articles were chosen in event-related potential and microbiome, respectively. All of them were original articles with control individual and patients with PD. According to the QUADAS-2 assessment of the studies, the risk of bias and applicability of the 
techniques based on the prodomical symptoms were described. The following describe the assessment used:

- MRI technique and prodomical symptoms

As shown in table 1, per the QUADAS-2 assessment, 14 studies (70\%) were identified as having a low risk of bias, 5 studies (30\%) were identified in the section of patients selection as high risk because the number of patients were significantly low as to determine the results, and 1 study as under risk, as demonstrated by the percentages in figure 2. All studies showed concerns regarding applicability.

The studies were an analysis on three main groups, 8 studies on cortical thickness, 6 studies on white and grey matter, and 6 studies on extrapyramidal. Many of them share and study similar topics, but the results had one principal objective. Taking into account this structure, we were able to consolidate which zones of the brain are more affective in promodomical symptoms. Figure 3 visualizes the percentage of risk of bias and applicability

- Event-related potential and prodomical symptoms

According to the QUADAS-2 assessment, shown in table 2, $12(85,7 \%)$ studies were identified as having high risk of bias in the section of patient selection as less than 50 patients could be a case of study, and 2 studies $(14,3 \%)$ were identified as low of risk. Figure 4 shows the risk of bias and the applicability of the studies where all studies showed concerns regarding applicability.

In this case, by the specificity of the search, in three groups studies divided; 3 papers for cognitive potential, 3 papers for olfactory potential, 6 papers for emotional potential, and 2 papers for sleep disorder. These potentials are the most researched regarding Parkinson's disease, knowing that there are more symptoms can also involucrate in the progress of the disease.

- Microbiome and prodomical symptoms

According to QUADAS-2 assessment (see table 3), 4 studies were identified as having a high risk of bias, the detection identified in this section were low compared with the other prodomical symptoms because the microbiome is still an unknown area in regards to Parkinson's disease (cita), the researcher and physicians are understanding and propousing hypothesis about how the bacteria can influence neurodegenetive disease. Figure 5 shows that 3 studies (75\%) having high risk were in the patient selection; this domain was classify thus, since in the applicability concerns were unclear for the low quantity of patient, and besides, it is still unknown which bacteria in relationship between gut and brain had a great influence.

\begin{tabular}{|c|c|c|c|c|c|c|c|}
\hline \multicolumn{8}{|c|}{ QUADAS -2 RESULTS } \\
\hline \multirow[t]{2}{*}{ Studies included } & \multicolumn{4}{|c|}{ Risk of bias } & \multicolumn{3}{|c|}{ Concerns about applicability } \\
\hline & $\begin{array}{c}\text { PATIENT } \\
\text { SELECTIO } \\
\mathbf{N}\end{array}$ & $\begin{array}{l}\text { INDEX } \\
\text { TEST }\end{array}$ & $\begin{array}{c}\text { REFERENCE } \\
\text { STANDARD }\end{array}$ & $\begin{array}{c}\text { FLOW } \\
\text { AND } \\
\text { TIMING }\end{array}$ & $\begin{array}{c}\text { PATIENT } \\
\text { SELECTIO } \\
\mathbf{N}\end{array}$ & $\begin{array}{l}\text { INDEX } \\
\text { TEST }\end{array}$ & $\begin{array}{c}\text { REFERENCE } \\
\text { STANDARD }\end{array}$ \\
\hline Study 1 & High & Low & Low & High & High & Low & Low \\
\hline Study 2 & High & Low & Low & Low & High & Low & Low \\
\hline Study 3 & High & Low & Low & Low & High & Low & Low \\
\hline
\end{tabular}




\begin{tabular}{|l|l|l|l|l|l|l|l|}
\hline Study 4 & Low & Low & Low & Low & High & Low & Low \\
\hline Study 5 & Low & Low & Low & Low & Low & Low & Low \\
\hline Study 6 & Low & Low & Low & Low & Low & Low & Low \\
\hline Study 7 & Low & Low & Low & Low & Low & Low & Low \\
\hline Study 8 & Low & Low & Low & Low & Low & Low & Low \\
\hline Study 9 & Low & Low & Low & Low & Low & Low & Low \\
\hline Study 10 & High & Unclear & Low & Low & High & Unclear & Low \\
\hline Study 11 & Low & Low & Low & Low & Low & Low & Low \\
\hline Study 12 & Low & Low & Low & Low & Low & Low & Low \\
\hline Study 13 & Low & Low & Low & Low & Low & Low & Low \\
\hline Study 14 & Low & Low & Low & Low & Low & Low & Low \\
\hline Study 15 & High & Low & Low & Low & High & Low & Low \\
\hline Study 16 & Low & Low & Low & Low & Low & Low & Low \\
\hline Study 17 & Low & Low & Low & Low & Low & Low & Low \\
\hline Study 18 & Low & Low & Low & Low & Low & Low & Low \\
\hline Study 19 & Low & Low & Low & Low & Low & Low & Low \\
\hline Study 20 & Unclear & Low & Low & Unclear & Unclear & Unclear & Low \\
\hline
\end{tabular}

Table 1. Results of risk of bias and concerns about applicability on MRI. QUADAS 2.

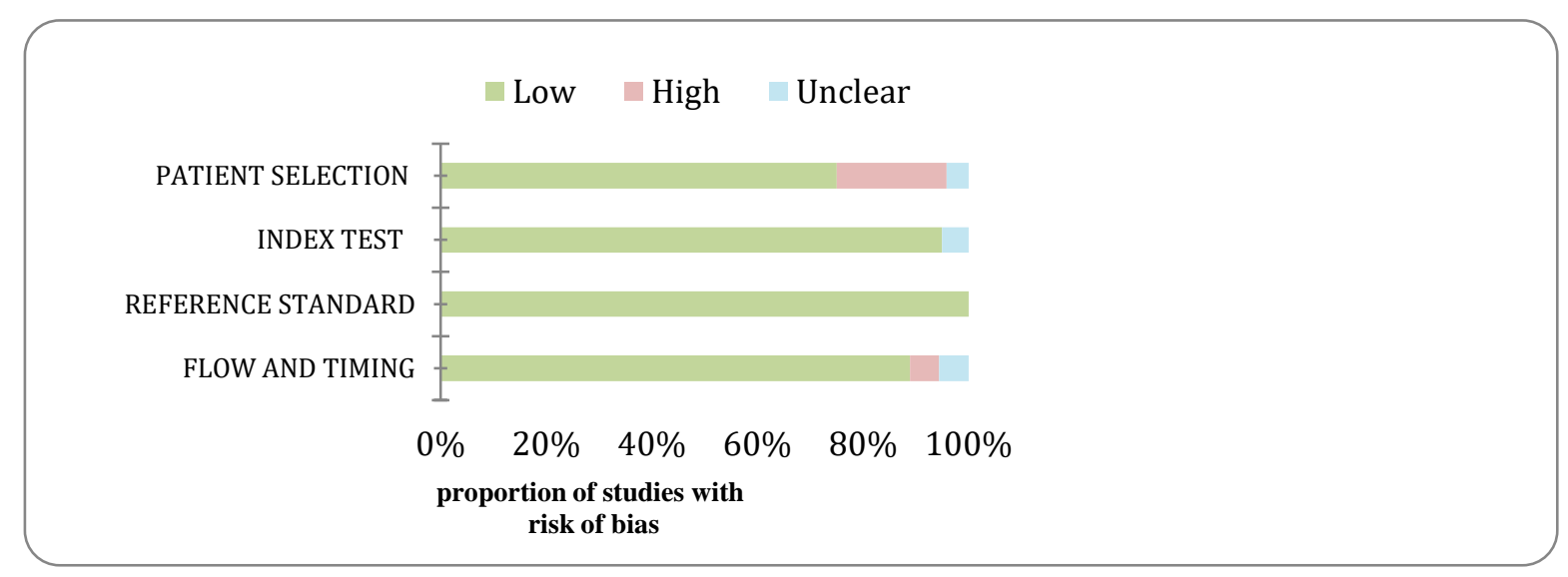

a) 


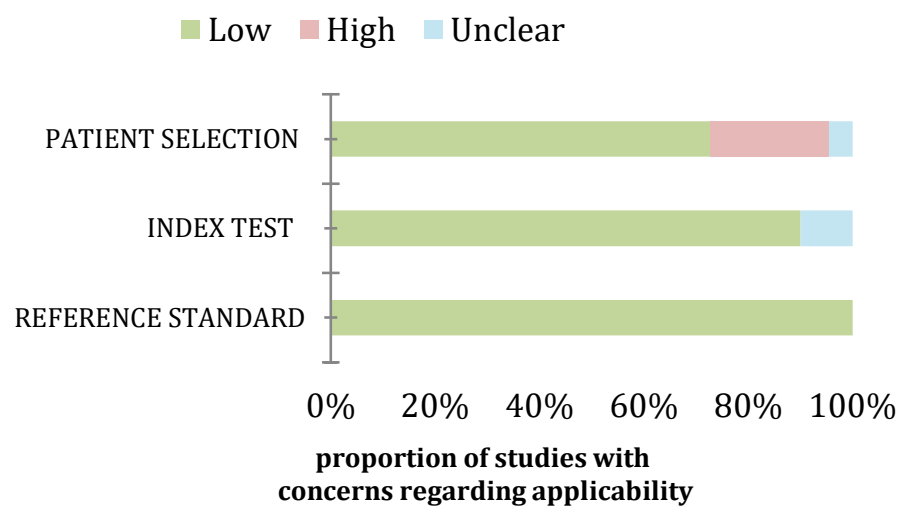

b)

Figure 3. Results of Quality Assessment Accuracy Studies of MRI and prodomical symptoms. Fig a. Risk of bias. Fig b. concerns about applicability

\begin{tabular}{|c|c|c|c|c|c|c|c|}
\hline \multicolumn{8}{|c|}{ QUADAS -2 RESULTS } \\
\hline \multirow[t]{2}{*}{ Studies included } & \multicolumn{4}{|c|}{ Risk of bias } & \multicolumn{3}{|c|}{ Concerns about applicability } \\
\hline & $\begin{array}{c}\text { PATIENT } \\
\text { SELECTION }\end{array}$ & $\begin{array}{l}\text { INDEX } \\
\text { TEST }\end{array}$ & $\begin{array}{l}\text { REFERENCE } \\
\text { STANDARD }\end{array}$ & $\begin{array}{c}\text { FLOW } \\
\text { AND } \\
\text { TIMING }\end{array}$ & \begin{tabular}{|c|} 
PATIENT \\
SELECTION
\end{tabular} & $\begin{array}{c}\text { INDEX } \\
\text { TEST }\end{array}$ & $\begin{array}{l}\text { REFERENCE } \\
\text { STANDARD }\end{array}$ \\
\hline \multicolumn{8}{|c|}{ Gruop 1 (Table 2) } \\
\hline Study 1 & High & Low & Low & Low & Unclear & Low & Low \\
\hline Study 2 & High & Low & Low & Low & Unclear & Low & Low \\
\hline Study 3 & High & Low & Low & Low & Unclear & Low & Low \\
\hline \multicolumn{8}{|c|}{ Group 2 (Table 2) } \\
\hline $\begin{array}{l}\text { Study } 4 \\
\end{array}$ & Low & Low & Low & Low & Low & Low & Low \\
\hline Study 5 & High & Low & Low & Low & Low & Low & Low \\
\hline Study 6 & Low & Low & Low & Low & Low & Low & Low \\
\hline \multicolumn{8}{|l|}{ Group 3 (table 2) } \\
\hline Study 7 & High & Low & Low & Low & Unclear & Low & Low \\
\hline Study 8 & High & Low & Low & Low & Unclear & Low & Low \\
\hline Study 9 & High & Low & Low & Low & Unclear & Low & Low \\
\hline Study 10 & High & Low & Low & Low & Unclear & Low & Low \\
\hline Study 11 & High & Low & Low & Low & Unclear & Low & Low \\
\hline Study 12 & High & Low & Low & Low & Unclear & Low & Low \\
\hline \multicolumn{8}{|l|}{ Group 4 (table 2) } \\
\hline Study 13 & High & Low & Low & Low & Unclear & Low & Low \\
\hline Study 14 & High & Low & Low & Low & Unclear & Low & Low \\
\hline
\end{tabular}

Table 2. Results of risk of bias and concerns about applicability on EEG. QUADAS 2. 


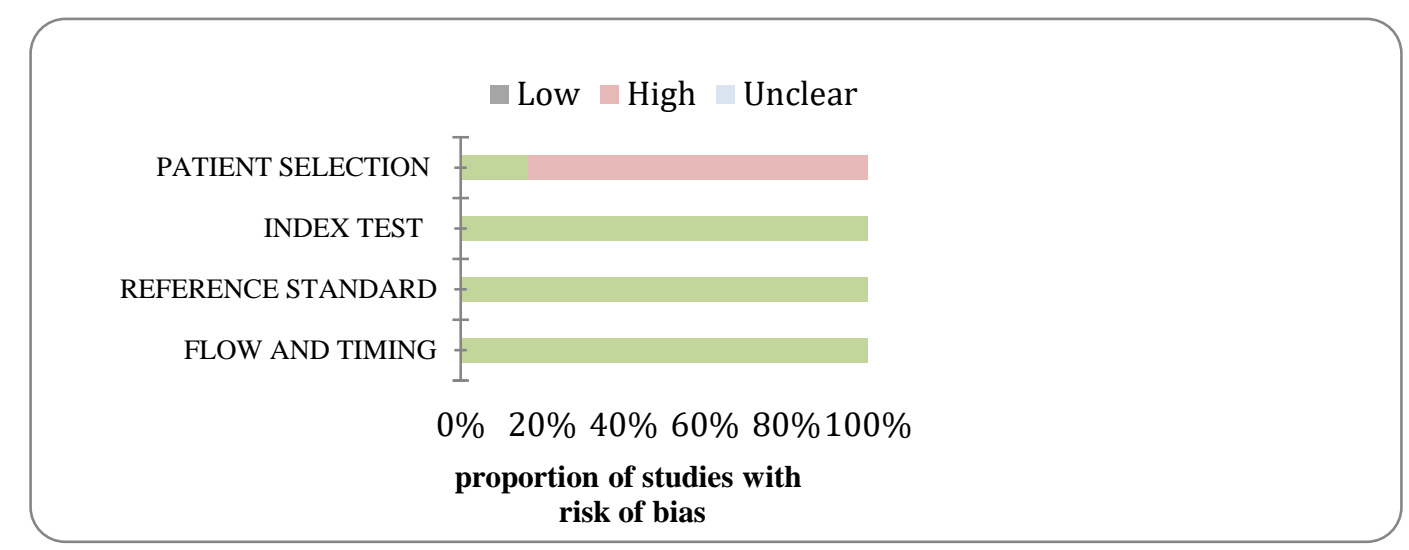

a)

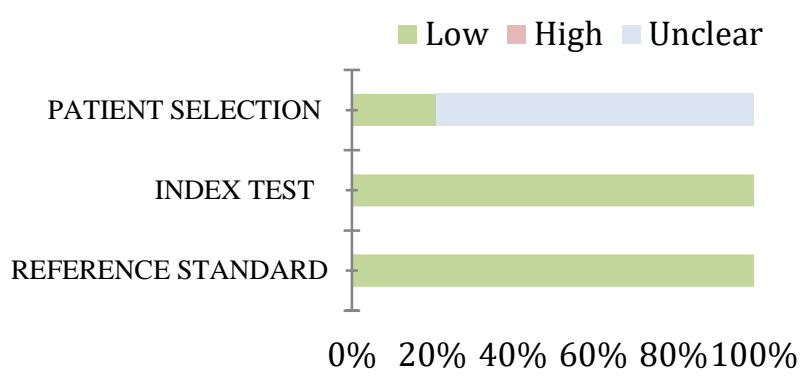

proportion of studies with concerns regarding applicability

b)

Figure 4. Results of Quality Assessment Accuracy Studies of EEG and prodomical symptoms. Fig a. Risk of bias. Fig b. concerns about applicability.

\begin{tabular}{|c|c|c|c|c|c|c|c|}
\hline \multicolumn{8}{|c|}{ QUADAS -2 RESULTS } \\
\hline \multirow[t]{2}{*}{ Studies included } & \multicolumn{4}{|c|}{ Risk of bias } & \multicolumn{3}{|c|}{ Concerns about applicability } \\
\hline & \begin{tabular}{|c} 
PATIENT \\
SELECTION
\end{tabular} & $\begin{array}{l}\text { INDEX } \\
\text { TEST }\end{array}$ & $\begin{array}{c}\text { REFERENCE } \\
\text { STANDARD }\end{array}$ & $\begin{array}{c}\text { FLOW } \\
\text { AND } \\
\text { TIMING }\end{array}$ & \begin{tabular}{|c} 
PATIENT \\
SELECTION
\end{tabular} & INDEX TEST & $\begin{array}{l}\text { REFERENCE } \\
\text { STANDARD }\end{array}$ \\
\hline Study 1 & High & Low & Low & Low & Unclear & Low & Low \\
\hline Study 2 & High & Low & Low & Low & Unclear & Low & Low \\
\hline Study 3 & High & Low & Low & Low & Unclear & Low & Low \\
\hline Study 4 & Low & Low & Low & Low & Low & Low & Low \\
\hline
\end{tabular}

Tabla 3 . Results of risk of bias and concerns about applicability on Microbiome QUADAS 2 


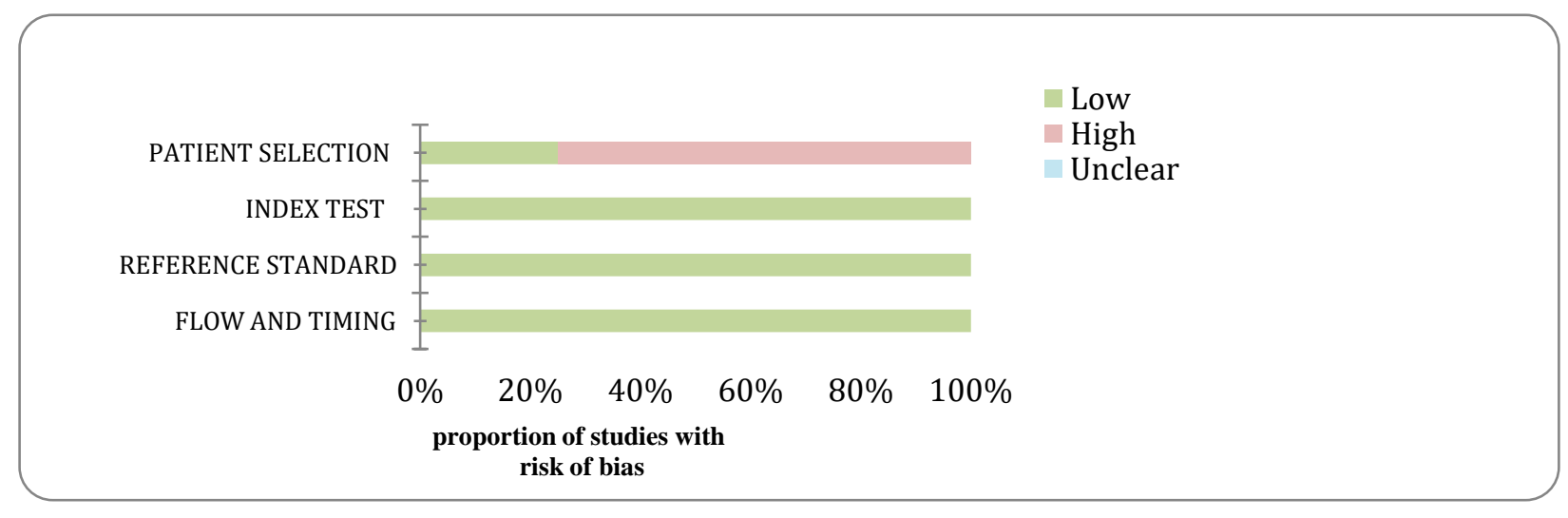

a)

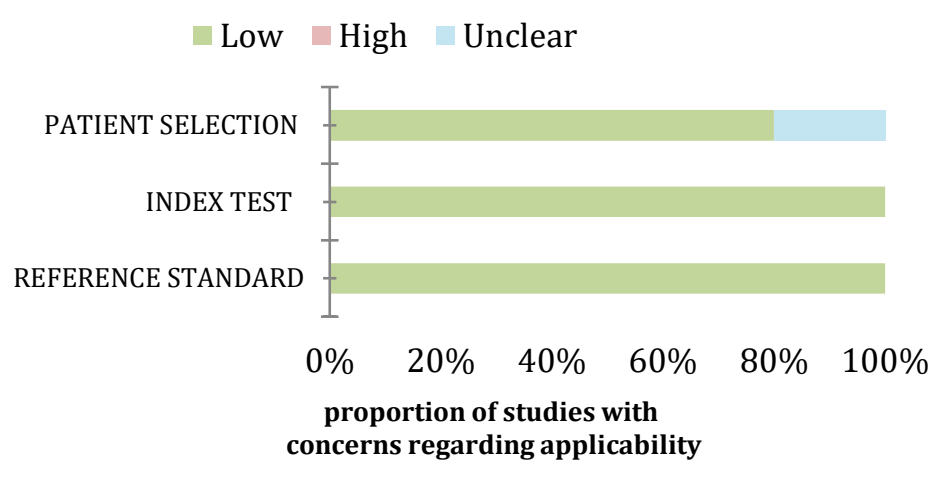

b)

Figure 5 Results of Quality Assessment Accuracy Studies of microbiome and prodomical symptoms. Fig a. Risk of bias. Fig b. concerns about applicability

\section{Development of subject}

After a systematic search applied the criteria of section 2, the progress of the topic focused on 38 articles where the studies targeted the non-motor symptoms of PD. Tables 4, 5 and 6 show the main contribution of each article. Taking this information, questions based on this systematic review were answered and the annotations are shown in the following paragraphs:

\subsection{Can MRI techniques find prodromal features of Parkinson's disease?}

When selecting studies to research neuroimaging in non-motor symptoms, the focus was an early diagnosis of PD trough magnetic resonance. In this section, we will consider the fundamental areas of the brain that are affected by PD as well as their associated symptoms. 
The influence of age with onset PD is still unknown. Some studies examine the correlation of some brains structures with age. However, it may be necessary to search for biomarkers of cognitive impairment in Parkinson's disease. The cortex is a clue of the brain's neurodegeneration, since this zone is the principal source of motor fibers of the pyramidal tract.

In order to apply techniques to investigate the progression of PD based on non-motor symptoms, data synthesis showed that patients may have Unified Parkinson's Disease Rating Scale (UPDRS) score between III and IV. After performing the MRI, the dataset had to develop a quality control in order to normalize the intensity and other characteristics that make images comparable.

\subsubsection{Cortical Thickness}

(Cerasa et al., 2013) analyzed the cortical thickness, a vertex by vertex multiple linear expression analysis, this was carried out to investigate the relationship between regional cortical thickness and scores of Abnormal Involuntary Movement Scale (May, et al, 1983). Dyskinetic PD patients mainly showed significantly thicker cortices, nevertheless, early-onset dyskinetic patients showed increased volume in a large cluster of the midbrain enclosed substantia nigra and red nucleus. (Mak et al., 2015) is a relevant research due to neuropsychological assessments at baseline. They compared regional percentage change of cortical thickness and subcortical atrophy over 18 months. These features showed significantly reduced cortical thickness in the frontal, parietal and occipital cortices: left supramarginal cortex, bilateral rostral middle frontal cortex, left isthmus cingulate and right posterior cingulate cortices, and the right lateral occipital cortex. On the other hand, (Kim et al., 2014) divided the brain into two areas, left-side-disease onset and right-side-disease onset. They modeled local cortical thickness as a linear relationship with the motor symptoms. In the first group, it found a cluster including the right primary sensory motor cortex and paracentral lobule, as well as another two clusters in bilateral parahippocampal gyrus. In the second group, there was just a cluster located in the left lingual gyrus. Moreover, they concluded that there is not relationship between the severity of motor symptoms and cortical thickness. (Potgieser et al., 2014) focused the research in the exposes that deteriorate the cortex in PD. In this case, the total gray matter per patient was calculated as to compare between PD patients and controls; the first instance reduction of regional gray matter density was not shown in anterior temporal regions. However, atrophy was observed in the left anterior temporal and inferior frontal region, while in the right hemisphere, posterolateral frontal atrophy was pronounced in a dorsal position.

(Wenzel et al., 2018) this work approach a rapid segmentation of subcortical brain structures in T1weight MRI by utilizing a shape-constrained deformable surface model. The advantage of this model is that can use of automated segmentation and volume quantification of different neurodegeneration disease.

\subsubsection{White and Gray matter}

Some of those studies performed functional magnetic resonance image (fMRI) in order to observe changes on the different areas of the brain while it is performing several tasks. (Canu et al., 2015) performed structural and functional magnetic resonance image. In this study, gray matter did not have atrophy in PD with freezing of gait; whereas white matter showed damage of the pedunculopontine tract, corpus callosum, corticospinal tract, cingulum, superior longitudinal fasciculus. (Gallagher et al., 2013) shows that the evolution of Parkinson's disease has been considered as an illness in which white matter abnormalities contribute to non-motor symptoms (Bohnen \& Albin, 2011). A magnetic resonance diffusion tensor was used as a measure of white matter microstructural integrity. This technique reported changes in hemispheric white matter in PD and these abnormalities contribute to cognitive deficits. (Zanigni et al., 2016) also analyses white matter, yet, this research differentiates 
progressive supranuclear palsy (PSP) from Parkinson disease. PSP is also a neurodegenerative disease that causes death in some areas of the brain and its symptoms are similar to PD. The results of that study show a high accuracy in differentiating between PSP and PD. (Agosta et al., 2013) researched on the damage to white and grey matter at different stages of PD. To achieve the results, the researchers analyzed the whole brain of patients and healthy controls. Patients divided into early PD stage and moderate PD. According to this classification, they found:

(1) PD patients had a very little gray matter atrophy, (2) white matter showed microstructural damage in PD patients, (3) the greatest difference evidenced in the pattern of white matter damage with moderate PD when compared to mild PD cases, and (4) the severity of white matter degeneration correlates with cognitive status.

(Amoroso, La Rocca, Monaco, Bellotti, \& Tangaro, 2018) made a classification model, the development is consisted in a brain connectivity based on grey and white matter voxel distribution; one that the segmentation threw the region interest, then they measure how different brain regions are correlated and for each region measure topological quantity. This model provides two important methodological understandings. Firstly, it associates to each node quantitative measurements which characterizes its role and importance within the network; secondly, it enables a description of the whole brain from a global perspective.

(Li, Xing, Martin-Bastida, Piccini, \& Auer, 2018) study the grey matter of PD, specifically on UPDRS III because some motor symptoms manifested at this point on the scale, but it is not still association with parkinsonian motor symptoms and neurodegeneration as reflected by grey matter. The results showed are not a correlation with UPDRS III score and putamen and caudate grey matter. However, rigidity sub-scores are associated with lower anterior striatal grey matter.

\subsubsection{Extrapyramidal system}

The extrapyramidal system is the zone most affected in PD; the pathway is the central nervous system of nigrostriatal, the basal ganglia, the cerebellum, the vestibular nuclei, and different sensory zones of the cerebral cortex (Zhang et al., 2015).

(Qiao, Shi, Jiang, Gao, \& Niu, 2017) analyzed the sequence of susceptibility-weighted imaging (SWI) and $\mathrm{T}$ weighted Imaging (T1wI) and T2wI to evaluate the contrast between the midbrain, basal nuclei, and the surrounding tissue, as well as the boundary clarity. The results showed a reduction on the signal intensities in the PD group indicated that there was a significant iron deposition in the nuclei of the PD patients.

On the other hand (Hutchinson \& Raff, 2008) and (Chen et al., 2014) segmented the zone of substantia nigra image in order to quantify the gradient of the pathological change. In the study of Hutchinson and Raff, there was a large evidence of differences between the patient and control group. Chen et al used a technique to quantify neuromelanin in the locus coeruleus and substantia nigra. This segmentation was performed in three steps: 1) ROIs were referenced with circles 2) Voxel intensities of the ROIs (substantia nigra and the mean) were calculated, 3) the intensity differences were calculated to create a binary map using a given criterion. Additionally, the volume of the locus coeruleus and substantia nigra was calculated in the same way. This technique demonstrated advantage in the image acquisition, image pre-processing and quantitative image.

(Lee et al., 2014) applied a technique that pretended to measure the volume of substantia nigra and 
basal forebrain with early Parkinson disease. In order to do that, the researchers divided the patients into three groups, 1) patients with stage $1 \mathrm{PD}, 2$ ) patients with stage $2 \mathrm{PD}$, and 3) patients with stage 3 PD. The results highlighted that the volume of substantia nigra was smaller on the left hemisphere in patients with stage 1 PD compared with the control group. The patients with stage 2 and 3 showed a smaller volume of the substantia nigra. Concerning the basal forebrain, its volume was not reduced in patients with stage $1 \mathrm{PD}$. On the other hand, the patients with stages 2 and 3 showed a significant reduction when compared to the controls.

(Takahashi et al., 2018) the study is about quantify nigral changes and neuromelanin values in whole substantia nigra pas compact containing the entire nigrosome and dorsolateral. The results showed, in both substantia nigra pars compact, quantify nigral changes were lower in PD patients. This affirmation, the MRI assessment of the abnormality of nigrosomes can produce an excellent diagnostic for early-stage PD.

(García-Lorenzo et al., 2013) the majority of PD patients'origin of rapid eye movement sleep behavior disorder, this non-motor symptom do not yet know how produce. For that reason, they use polysomnography and MRI 3T to assess the locus subcoeruleus in the brain stem, the zones which are implicated with the rapid eye movement sleep behavior disorder. The results confirmed that in Parkinson's disease, this complex is affected, and there is a gradual damage of the structure.

(Ziegler et al., 2013) focused on the hypothesis that the degeneration of substantia nigra pars compact yield that of the cholinergic basal forebrain in PD. The patients were assessed with Hoehn and Yahr (H\&Y) stages I-III (Perlmutter, 2009). Following the MRI protocol they used, the images provide a study window on the subcortical structure that are concerned with PD, but this protocol cannot be carried out with conventional MRI.

(Rolheiser et al., 2011) proposed a study that assess the olfactory non-motor symptom and diffusion tensor image; in the MRI examined olfactory tract and substantia nigra. During the olfactory test, shown impairment in the test and the diffusion tensor image showed differences between olfactory region and substantia nigra. (Moessnang et al., 2011) also related with olfactory disorder as nonmotors symptom. The researchers combined olfactory test and fMRI to analyze the activation olfactory network of PD patients. PD patients showed network dysfunction that need to be studied further.

\subsection{Can potential event-related EEG show early signs of Parkinson's disease?}

The selection of studies that carry out EEG related to events can provide a different set of features for Parkinson's disease. These measurements, through previously stipulated brain stimulations, show peaks which appear in the EEG in response to the occurrence of an event. Now we classify the different studies depending on the nature of the stimulus.

\subsubsection{Cognitive event.}

This cognitive section of Parkinson's disease focuses on Event Related Potential ERP with the purpose of characterizing the response to cognitive events (Özmüş et al., 2017). The following studies use different techniques to measure the signal, but their respective conclusions can be compared. (Yuvaraj, Rajendra Acharya, \& Hagiwara, 2018) and (Oh et al., 2018) related to the computational analysis of the signals, and the third is about the cognitive impairment of PD. Computational automated techniques are able to aid in the early detection of PD. In the casa of Yuvaraj, a high level technique was used to contribute to the diagnosis of the PD, in the developing of such techniques, the discrimination of the abnormalities signal and normal report the explicitly of PD signal.. (Oh et al., 
2018) used automated classification of EEG signal in their study. In this case, they classified signals using the technique of the convolutional neuronal network to identify early symptoms of abnormalities. (Özmüş et al., 2017) studied brain dynamics of early PD patients and controls using event-related potential. The patients in this case diagnosed neurological tests to be cognitively normal. However, in EEG after applying P300 amplitude, results indicate that PD patient's signals were significantly lower at the F3, Fz, Cz, Cz, P4, and Pz electrode sites.

\subsubsection{Olfactory event.}

The olfactory loss is an ambivalent non-motor symptom of PD because a patient with respiratory issues may also have hyposmia. However, years before the motor symptom appears, a manifestation of hyposmia can appear in PD, which can be an alert for this type of neurodegenerative illness. For that reason, in this systematic review, we took into consideration the articles of the second group in table 1 (Iannilli, Stephan, Hummel, Reichmann, \& Haehner, 2017) (Versace et al., 2017) (Cozac et al., 2017). These studies are based on EEG-derived ERP, which are changes in voltage that occur at a given moment while a stimulus is applied (Iannilli et al., 2017). In this case, the stimulus is odor and the amplitude and latencies of response are measured. This study was able to show that there is a reduction of olfactory sensitivity in PD patients, which was observed at EEG-derived ERP. These responses could be detected on specific brain cortex areas: the right angular gyrus, the right parahippocampal gyrus and the right cingulate gyrus. (Versace et al., 2017) applied two techniques: Short latency Afferent Inhibition (SAI) to study the cholinergic function and olfactory event related potential to evaluate the olfactory system. Cholinergic function focused on electrical stimuli to a peripheral nerve with the purpose to assess sensorimotor system (Turco, C. V., El Sayes, J., Locke, M. B., Chen, R., Baker, S., \& Nelson, 2018). Using both techniques, they could observe a significant reduction in this putative marker of central cholinergic activity in PD patients. The Olfactory Event Related Potential (OERP) abnormalities indicated cognitive deterioration. Thus, provided findings support the fact that cholinergic denervation is a robust determinant of hyposmia, and raises the possibility that the presence of olfactory dysfunction may indicate increased risk of cognitive impairment in patients with PD. In (Cozac et al., 2017), the objective was to identify the mutual influence of olfactory sensitivity decrease and EEG changes in PD. Within the research, they discriminate three relevant aspects:

- Olfactory lost is considerably greater in PD patients than in healthy controls; this decline in PD is yet to be completely understood.

- There is an association between odor impairment and motor degeneration, more specifically with gait and rigidity. It may be explained by the projections from the olfactory regions to the brain structure (Wilson DA, Chaouis J, 2015).

- There is no association between olfactory loss and the resting-state EEG power spectrum. The principal reason for this fact is the different rates of neurodegeneration (Domellöf ME, Lundin K-F, Edström M, 2017).

\subsubsection{Emotional event.}

The response of the emotional component has an important role in the organism. These events may be internal (thoughts, memories, sensations) and external (stimulus, people's behavior, a change of situation) (Gray HM, 2010). From the physiological point of view, this leads to the fact of activation of neurotransmitters in the autonomic nervous system, which are associated with emotional states. The emotional changes can be even more problematic than motor decline in PD. In the literature, scientifics have reported discrepancies in emotional process (Sotgiu, I., \& Rusconi, 2013). These include various changes on it, but mostly in the recognition of emotions 
In this context, electrophysiology measures may be a method to assess the problematic on PD patients (Stimuli Hiroyuki Oya, Hiroto Kawasaki, Matthew A. Howard, 2002). The articles evaluated in this section use EEG-derived ERP to asses emotional process while showing short videos or image that express happiness, surprise, anger,sadness or fear. (Garrido-Vásquez, Pell, Paulmann, Sehm, \& Kotz, 2016) carried out a neuronal analysis using eventrelated potential. The applied stimulus was a dynamic facial display that produced emotional sentences in a happy, angry and neutral voice. This study reported that left Parkinson Disease patients, whose right hemisphere is predominantly affected by neural degeneration, exhibited impairments during the first $200 \mathrm{~ms}$ of face processing.

In this systematic review, we reported an author (Yuvaraj) who has worked in the emotional field with 4 studies (Yuvaraj \& Murugappan, 2016) (Yuvaraj et al., 2016) (Yuvaraj, Murugappan, Mohamed Ibrahim, et al., 2014) (Yuvaraj, Murugappan, Ibrahim, et al., 2014). In these studies, the emotional stimuli was caused by emotions such us sadness, happiness, fear, anger and surprise. (Yuvaraj \& Murugappan, 2016) reported a nonlinear analysis of EEG during emotion processing in PD patients. In this case, they analyze the emotional processing in right-side affected and left-side affected patients. The authors found that in order to classify it is better to differentiate between high frequencies (alpha, beta, and gamma bands) than low frequencies (delta and theta band). These results reported that neuronal degeneration in PD could contribute to the decline of emotional recognition. However, lateralization of emotion has been debated and asymmetric effects on explicit emotion have been reported (Clark, Neargarder, \& Cronin-Golomb, 2008) (Ariatti A, Benuzzi F, 2008) (Ventura MI, Baynes K, Sigvardt KA, Unruh AM, Acklin S, Kirsch HE, 2012).

(Yuvaraj et al., 2016) further investigated the emotion recognition in PD using EEG and based Brain Functional Connectivity (BFC) patterns. In order to make the BFC, the researchers used a correlation coefficient to analyze the emotional state, the degree of coherence in the band EEG report since the coherence of each emotion can change and the synchronization index between right and left frontal sites while viewing the emotions. In view of the performance of these values, they compared the BFC index using computational techniques. The results showed PD patients show a decline in the functional connectivity indices during emotional stimulation.

(Yuvaraj, Murugappan, Mohamed Ibrahim, et al., 2014) focused on the detection of six emotions in PD patients when compared to healthy individuals with individuals classified using a computational model. The classification supported the assessment of emotional impairment associated to non-motor symptoms of PD. The categorization was developed using computational methods, applying machine learning to emotion categories. This process found that the easiest emotions to classify were happiness and surprise while the most difficult were disgust and sadness. An intermediate difficulty was found for anger and fear. Those successes can demonstrate dysfunction in specific neuronal circuits. These include amygdala and the ventral striatum which are located within the basal ganglia's limbic loop.

(Yuvaraj, Murugappan, Ibrahim, et al., 2014) examined the PD patient's emotion-processing deficit in EEG signal (theta, gamma, betha and alpha). The results suggest the likelihood of the presence of a distinctive neurobiological substrate of PD patients during emotional information processing. Moreover, it was found an increase in power in the theta and gamma bands for PD patients. The last article of Table 2 group 3 was (Dietz et al., 2013). Its objective was to investigate the electrophysiology indices of brain response during emotional process. This could be carried out measuring emotions during picture processing in the amplitude of the late positive potential (LPP). The pictures used to measure LPP were pleasant, neutral, and unpleasant pictures. The results showed a reduction in LLP amplitude when PD patients viewed unpleasant, compared to pleasant pictures and healthy controls. 


\subsection{Sleep disorder.}

The period of premotor symptoms of Parkinson's disease manifests on the brainstem and midbrain, while the symptomatology is located in these zones. The symptoms could be as many as autonomic changes, depression, olfactory dysfunction, and sleep disorder. Idiopathic rapid behavior disorder (iRBD) has confirmed to be a preclinical feature because iRBD patients develop a synucleinopathy (YuanYuan, 2017). (Hansen, Marcussen, Christensen, Jennum, \& Sorensen, 2013) classified subjects dependent on the power of EEG signal at different frequency bands. This classification was made using K-means and Bayesian classifiers. As a result, the study obtained Bayesian classifiers that reached $90 \%$ of sensitivity and specificity. Regarding the brain, five features attained a worthy classification. All came from the O1-A2 and F3-A2 signals, both located in the left hemisphere of the brain. The paper of (Iwanami, Miyamoto, Miyamoto, Hirata, \& Takada, 2010) provides reliable information because the study performed three techniques to assess two non-motor symptoms as PD olfactory loss and iRDB. The techniques were Polysomnography (PSG), odor identification and Sonography. Results showed substantia nigra hyperechogenicity and abnormal functional anosmia or hyposmia.

\subsection{Can microbiome show early signs of Parkinson's disease?}

Modern civilization is confronted with a progressive increase in mental diseases, such as anxiety and depression. As a hypothesis, inflammation of the gut has a relationship with those situations. The gut-brain-axis refers to communication between central nervous system and gut microbiome (Clapp et al., 2017). According to that, Parkinson disease may start in enteric nervous system and spread via the vagal nerve to the brainstem.

(F, Hopfner, Künstner A, Müller SH, Künzel S, Zeuner KE, Margraf NG, Deuschl G, Baines JF, 2017) determined whether PD is related to qualitative or quantitative changes in the gut microbiota. In these results, Lactobacillaceae, Barnesiellaceae and Enterococcacea were more abundant in patients with Parkinson's disease. Nevertheless, gut microbiome requires more investigation and it is necessary to establish the role of the microbiome. According to (Agata Mulak, Slawomir Budrewicz, Magdalena Panek-Jeziorna, Magdalena Koszewicz, Maria Jasinska, Beata Marczak-Karpina, Krzysztof Slotwinski, Ryszard Podemski, 2017) Parkinson's disease is characterized by alphasynucleinopathy at all levels of the brain-gut axis, whose alterations in enteric nervous system ENS contribute to the manifesting of PD. Therefore, increased levels of calprotectin and zonulin in stool samples found in $60 \%$ and $40 \%$ of PD patients respectively. The stool ELISA that confirmed the changes in the intestinal microbiome of PD patients. (Unger et al., 2016) hypothesized that a shift in gut microbiome might be associated with short chain fatty acids (SCFA) that are in the colon and produce bacterial carbohydrate fermentation (Joseph E.Pizzorno, Michael T.Murray, 2016). The results report that stool SCFA concentrations reduced in PD patients. Regarding the bacterial family found, Bacteroidetes and Prevotellaceae had decreased concentrations while Enterobacteriaceae were more abundant. However, (Scheperjans et al., 2015) report that PD gut microbiome has not been sufficiently researched and there is no definite evidence of any specific microbe being linked to PD. The purpose of the study was to compare the composition of the whole stool microbiome between PD patients and healthy individuals. The results reported that the bacterial family concentration in feces had a low quantity of prevotellaceae and an increased abundance of enterobacteriaceae. 


\section{Discussion}

Our systematic review found that MRI, EPR and microbiome are techniques very influential in analyzing the non-motor symptoms of Parkinson's disease because of the ability to try and obtain relevant results to determine prodromal features. This paper has selected $n=38$ studies with of a total of $n=5,592$ PD patients and a total of healthy controls $n=538$. Our results, however, had several restrictions depending on the techniques. Neuroimaging was restricted to individual imaging modalities (structural MRI), the EEG restriction was ERP (cognitive, olfactory and emotional) and the restriction of microbiome was the study of fecal samples. None of these techniques employed simultaneously for the same study, so the possible synergy given by the combination of the three is still to be determined in the future.

The results of these studies indicate a higher sensitivity associated with fMRI data as related to brain functionality (Uribe et al., 2018). On the other hand, using structural MRI is possible to observe changes in cortex zone, basal nucleus (when motor symptoms already manifested on the body). Furthermore, structural MRI allows the construction of a brain volume in order to observe changes as a tool to detect changes in several areas of the brain. However, this complex work is still to be totally done. Furthermore, fMRI may be a relevant method because it can be used with protocols of olfaction, emotional with propose to analyze the sensitivity of the brain through an event. This application of fMRI will facilitate the comparison of results obtained by ERP by simply sharing similar protocols that can be used in both techniques and can provide a general point of view (Matsuda, Matsuura, \& Ohkubo, 2002).

The most common technique to evaluate and measure non-motor symptoms is diffusion tensor image (DFI). The majority of included studies used it, since DTI estimated regions through magnetic field directions to create an image that is briefed in a particular direction. A recent study showed that by using this technique, relevant longitudinal connectomes compared with other studies can be understood (Peña-nogales, Ellmore, Luis-garcía, \& Lambert, 2019).

We observe substantial results concerning the use of ERP to investigate the effect of different stimulus in order to analyze latencies and amplitudes. It has been reported that non-motor symptoms in PD are associated with oscillations in all frequencies ranges (Bočková \& Rektor, 2018). However, there is still a lack of information in the scale brain-networks about non-motor symptoms. In the search, we found evidence of olfactory, emotional and cognitive assess, which are principal Non-motor Symptoms (NMS). For example, in emotional stimulus, frontal areas play an important role as revealed by the P100 and P200 amplitudes (A. Semertzidou, C.A. Frantzidis, A. Ladas, M. Karagianni, M. Tsolaki, 2012). The olfactory bulb is affected in the early stages of PD, with olfactory stimulus with patients who have Parkinson disease at stage III evidenced having the latency substantially diminished. It should be noted that there is still a need for investigations on the ERP technique on prodromal symptoms in PD.

Mollenhauer (Mollenhauer et al., 2016) mentions that could be the most common non-motor symptoms that can affect the development of PD on a person. In their protocols, they examined a non-motor Symptom Scale. To develop this study, they selected the following NMS: cognitive function, REM sleep behavior disorder by polysomnography, voxel-based morphometry (VBM) of the brain by MRI, and Cerebrospinal Fluid (CSF). The study concluded that the sleep and imaging measures as other NMP are necessary in adequate scales and may lead to obtaining more features to quantify the progression of PD. 
Our review also researched microbiome. Microbiome is still an unknown topic to research and there is much to study. Brain-gut axis seems to have a stretch relationship with neurodegeneration diseases, and mostly with PD. It would be interesting to conduct tests to investigate questionnaire data and stool samples to realize the relationship between constipation symptoms, bacterium families and PD. Moreover, the association between the abundance of microbiome and medication is also interesting in PD levodopa because pharmacological treatment regularly causes gastrointestinal side effects.

The combination of these three techniques could become increasingly useful in the diagnosis of early stage Parkinson's disease; subsequently it would contribute unified information that can interpret data from the gut and the brain. The literature says these huge organs communicate between each other which could provide the influence of some microbes in Parkinson's disease to somehow cause the death of dopamine cells.

\section{Conclusions}

In the past decade, significant improvement has been made on numerous fronts in combined EEG and MRI studies of the Parkinson's disease. These include optimal study design that goes from the acquisition to the analysis of the data. An area that clearly needs further research is the development and validation of procedures for microbiome in PD. Such models will help researchers to better integrate the microbes with the central nervous system. Having this information could incorporate this information with MRI and EEG signal.

Alongside this, we analyzed some published papers that assess PD focusing on motor and non-motor symptoms using MRI, ERP and microbiome. The evidence of motor symptoms is large and by means of MRI is already feasible to know and observe which features are affected in the brain. Nowadays, through the use of computational tools, it is possible to study the progression of PD, but the evidence of non-motors symptoms on MRI is still a field that needs to be explored. Although, there is already a timeline and list of the non-motor symptoms that perhaps could produce the disease on the basal nucleus. However, the physicians do not have all the predominant features to diagnose PD as soon as possible. Furthermore, there are no baseline studies that observe the changes on patients with early Parkinson's disease.

On the other hand, using ERP allows detecting PD features in a very reliable way. Investigating whether PD patients have trouble to distinguish emotions and how depression affects the brain's signals allows for the detection of cognitive impairment. Concerning olfactory loss, in order to have an accuracy research, the researchers need to focus on known odors for Parkinson's disease patients in order to determine if there is a real loss of smell.

Finally, microbiome might include the classification of bacterial families and this may increase accuracy in the exploration of fecal samples to find potential features of Parkinson's disease. For all these reasons, we consider that the combination of the previous techniques, with the support of computation, can provide a set of biomarkers that can help in the diagnosis of Parkinson's disease in the earlier stages. 


\section{REFERENCES}

A. Semertzidou, C.A. Frantzidis, A. Ladas, M. Karagianni, M. Tsolaki, P. D. B. (2012). How aging affects emotional processing? Neurophysiological evidence using passive emotion evocative stimuli selected from the International Affective Picture System (IAPS). Poster Abstracts/International Journal of Psychophysiology, 85(3), 361-430. https://doi.org/10.1016/j.ijpsycho.2012.07.122

Agata Mulak, Slawomir Budrewicz, Magdalena Panek-Jeziorna, Magdalena Koszewicz, Maria Jasinska, Beata Marczak-Karpina, Krzysztof Slotwinski, Ryszard Podemski, L. P. (2017). Fecal Biomarkers of Gut Inflammation and Intestinal Barrier Dysfunction in Parkinson's Disease. Gastroenterology, 152, S924. https://doi.org/10.1016/S0016-5085(17)33152-9

Agosta, F., Canu, E., Stojković, T., Pievani, M., Tomić, A., Sarro, L., ... Filippi, M. (2013). The topography of brain damage at different stages of parkinson's disease. Human Brain Mapping, 34(11), 2798-2807. https://doi.org/10.1002/hbm.22101

Amoroso, N., La Rocca, M., Monaco, A., Bellotti, R., \& Tangaro, S. (2018). Complex networks reveal early MRI markers of Parkinson's disease. Medical Image Analysis, 48, 12-24. https://doi.org/10.1016/j.media.2018.05.004

Barber, T. R., Klein, J. C., Mackay, C. E., \& Hu, M. T. M. (2017). Neuroimaging in pre-motor Parkinson's disease. NeuroImage: Clinical, 15(April), 215-227. https://doi.org/10.1016/j.nicl.2017.04.011

Bočková, M., \& Rektor, I. (2018). Impairment of brain functions in Parkinson's disease reflected by alterations in neural connectivity in EEG studies: a viewpoint. Clinical Neurophysiology, 130, 239-247. https://doi.org/10.1016/J.CLINPH.2018.11.013

Braak, H., Del, K., Rüb, U., Vos, R. A. I. De, Jansen, E. N. H., \& Braak, E. (2003). Staging of brain pathology related to sporadic Parkinson's disease, 24, 197-211.

Canu, E., Agosta, F., Sarasso, E., Volontè, M. A., Basaia, S., Stojkovic, T., ... Filippi, M. (2015). Brain structural and functional connectivity in Parkinson's disease with freezing of gait. Human Brain Mapping, 36(12), 5064-5078. https://doi.org/10.1002/hbm.22994

Caputi, V., \& Giron, M. C. (2018). Microbiome-Gut-Brain Axis and Toll-Like Receptors in Parkinson 's Disease. International Journal of Molecular Sciences, 1-19. https://doi.org/10.3390/ijms19061689

Cerasa, A., Salsone, M., Morelli, M., Pugliese, P., Arabia, G., Gioia, C. M., ... Quattrone, A. (2013). Age at onset influences neurodegenerative processes underlying PD with levodopainduced dyskinesias. Parkinsonism and Related Disorders, 19(10), 883-888. https://doi.org/10.1016/j.parkreldis.2013.05.015

Chen, X., Huddleston, D. E., Langley, J., Ahn, S., Barnum, C. J., Factor, S. A., ... Hu, X. (2014). Simultaneous imaging of locus coeruleus and substantia nigra with a quantitative neuromelanin MRI approach. Magnetic Resonance Imaging, 32(10), 1301-1306. https://doi.org/10.1016/j.mri.2014.07.003

Clapp, M., Aurora, N., Herrera, L., Bhatia, M., Wilen, E., \& Wakefield, S. (2017). Gut microbiota's effect on mental health: the gut-brain axis. Clinics and Practice, 7(4). https://doi.org/10.4081/cp.2017.987

Cozac, V. V., Auschra, B., Chaturvedi, M., Gschwandtner, U., Hatz, F., Meyer, A., ... Fuhr, P. (2017). Among early appearing non-motor signs of parkinson's disease, alteration of olfaction but not electroencephalographic spectrum correlates with motor function. Frontiers in Neurology, 8(OCT), 1-6. https://doi.org/10.3389/fneur.2017.00545

Dietz, J., Bradley, M. M., Jones, J., Okun, M. S., Perlstein, W. M., \& Bowers, D. (2013). The late positive potential, emotion and apathy in Parkinson's disease. Neuropsychologia, 51(5), 960966. https://doi.org/10.1016/j.neuropsychologia.2013.01.001

F, Hopfner, Künstner A, Müller SH, Künzel S, Zeuner KE, Margraf NG, Deuschl G, Baines JF, K. G. (2017). Gut microbiota in Parkinson disease in a northern German cohort. Brain Research, 
1667, 41-45. https://doi.org/10.1016/j.brainres.2017.04.019

Gallagher, C., Bell, B., Bendlin, B., Palotti, M., Okonkwo, O., Sodhi, A., ... Alexander, A. (2013). White matter microstructural integrity and excutive fuctions in parkinson's disease. Political Science, 5(2), 361-362. https://doi.org/10.1017/S1

García-Lorenzo, D., Longo-Dos Santos, C., Ewenczyk, C., Leu-Semenescu, S., Gallea, C., Quattrocchi, G., ... Lehericy, S. (2013). The coeruleus/subcoeruleus complex in rapid eye movement sleep behaviour disorders in Parkinson's disease. Brain, 136(7), 2120-2129. https://doi.org/10.1093/brain/awt152

Garrido-Vásquez, P., Pell, M. D., Paulmann, S., Sehm, B., \& Kotz, S. A. (2016). Impaired neural processing of dynamic faces in left-onset Parkinson's disease. Neuropsychologia, 82, 123133. https://doi.org/10.1016/j.neuropsychologia.2016.01.017

Gershanik, O. S. (2017). Does Parkinson's disease start in the gut? Arq Nueropsiquiatr, (October), $67-70$.

Hamm-clement, J., \& Sandmann-keil, D. (2002). Staging of the intracerebral inclusion body pathology associated with idiopathic Parkinson's disease ( preclinical and clinical stages ). Journal of Neurology, 1-5. https://doi.org/10.1007/s00415-002-1301-4

Hansen, I. H., Marcussen, M., Christensen, J. A. E., Jennum, P., \& Sorensen, H. B. D. (2013). Detection of a sleep disorder predicting Parkinson's disease. Proceedings of the Annual International Conference of the IEEE Engineering in Medicine and Biology Society, EMBS, (from 2004), 5793-5796. https://doi.org/10.1109/EMBC.2013.6610868

Hutchinson, M., \& Raff, U. (2008). Detection of Parkinson's disease by MRI: Spin-lattice distribution imaging. Movement Disorders, 23(14), 1991-1997. https://doi.org/10.1002/mds.22210

Iannilli, E., Stephan, L., Hummel, T., Reichmann, H., \& Haehner, A. (2017). Olfactory impairment in Parkinson's disease is a consequence of central nervous system decline. Journal of Neurology, 264(6), 1236-1246. https://doi.org/10.1007/s00415-017-8521-0

Iwanami, M., Miyamoto, T., Miyamoto, M., Hirata, K., \& Takada, E. (2010). Relevance of substantia nigra hyperechogenicity and reduced odor identification in idiopathic REM sleep behavior disorder. Sleep Medicine, 11(4), 361-365. https://doi.org/10.1016/j.sleep.2009.12.006

Kelly Del Tredici, Udo Rüb, Rob A.I de Vos, Jürgen R.E. Bohl, and H. B. (2002). Where Does Parkinson Disease Pathology Begin in the Brain? Journal of Neuropathology and Experimental Neurology, 61(5), 413-426.

Kim, J. S., Yang, J. ju, Lee, J. min, Youn, J., Kim, J. min, \& Cho, J. W. (2014). Topographic pattern of cortical thinning with consideration of motor laterality in Parkinson disease. Parkinsonism and Related Disorders, 20(11), 1186-1190. https://doi.org/10.1016/j.parkreldis.2014.08.021

Lee, H. M., Kwon, K. Y., Kim, M. J., Jang, J. W., Suh, S. il, Koh, S. B., \& Kim, J. H. (2014). Subcortical grey matter changes in untreated, early stage Parkinson's disease without dementia. Parkinsonism and Related Disorders, 20(6), 622-626. https://doi.org/10.1016/j.parkreldis.2014.03.009

Li, X., Xing, Y., Martin-Bastida, A., Piccini, P., \& Auer, D. P. (2018). Patterns of grey matter loss associated with motor subscores in early Parkinson's disease. NeuroImage: Clinical, 17(November 2017), 498-504. https://doi.org/10.1016/j.nicl.2017.11.009

Mahlknecht, P., Seppi, K., \& Poewe, W. (2015). The Concept of Prodromal Parkinson's sisease. The Journal of Parkinson's Disease, 5, 681-697. https://doi.org/10.3233/JPD-150685

Mak, E., Su, L., Williams, G. B., Firbank, M. J., Lawson, R. A., Yarnall, A. J., ... O’Brien, J. T. (2015). Baseline and longitudinal grey matter changes in newly diagnosed Parkinson's disease: ICICLE-PD study. Brain, 138(10), 2974-2986. https://doi.org/10.1093/brain/awv211

Matsuda, T., Matsuura, M., \& Ohkubo, T. (2002). Influence of arousal level for functional magnetic resonance imaging ( fMRI) study: Simultaneous recording of fMRI and electroencephalogram. Psychiatry and Clinical Neurosciences, 56, 289-290. 
https://doi.org/10.1046/j.1440-1819.2002.01016.x

Moessnang, C., Frank, G., Bogdahn, U., Winkler, J., Greenlee, M. W., \& Klucken, J. (2011). Altered activation patterns within the olfactory network in Parkinson's disease. Cerebral Cortex, 21(6), 1246-1253. https://doi.org/10.1093/cercor/bhq202

Oh, S. L., Hagiwara, Y., Raghavendra, U., Yuvaraj, R., Arunkumar, N., Murugappan, M., \& Acharya, U. R. (2018). A deep learning approach for Parkinson's disease diagnosis from EEG signals. Neural Computing and Applications, (August). https://doi.org/10.1007/s00521-0183689-5

Özmüş, G., Yerlıkaya, D., Gökçeoğlu, A., Emek Savaş, D. D., Çakmur, R., Dönmez Çolakoğlu, B., \& Yener, G. G. (2017). Demonstration of early cognitive impairment in Parkinson's disease with visual p300 responses. Noropsikiyatri Arsivi, 54(1), 21-27. https://doi.org/10.5152/npa.2016.12455

Peña-nogales, Ó., Ellmore, T. M., Luis-garcía, R. De, \& Lambert, C. (2019). Longitudinal Connectomes as a Candidate Progression Marker for Prodromal Parkinson 's Disease. Frontier in Neuroscience, 12(January), 1-13. https://doi.org/10.3389/fnins.2018.00967

Penny F.Whiting; Anne W.S Rutjes; Marie E. Westwood; Susan Mallett; Jonathan J. Deeks; Jahannes B. Reitsma; Mariska M.G. Leeflang; Jonathan A.C. Sterne; Patrick M.M. Bossuyt; and the group of quadas-2. (2011). QUADAS-2: A Revised Tool for the Quality Assessment of Diagnostic Accuracy Studies. Ann Intern Med, (4), 529-536. Retrieved from https://annals.org/aim/fullarticle/474994/quadas-2-revised-tool-quality-assessment-diagnosticaccuracy-studies

Perlmutter, J. S. (2009). Assessment of Parkinson Disease Manifestations. In Current protocols in neuroscience (pp. 1-16). https://doi.org/10.1002/0471142301.ns1001s49.Assessment

Potgieser, A. R. E., Van Der Hoorn, A., Meppelink, A. M., Teune, L. K., Koerts, J., \& De Jong, B. M. (2014). Anterior temporal atrophy and posterior progression in patients with parkinson's disease. Neurodegenerative Diseases, 14(3), 125-132. https://doi.org/10.1159/000363245

Pyatigorskaya, N., Gallea, C., Garcia-lorenzo, D., \& Vidailhet, M. (2014). A review of the use of magnetic resonance imaging in Parkinson' s disease, 206-220.

https://doi.org/10.1177/1756285613511507

Qiao, P. F., Shi, F., Jiang, M. F., Gao, Y., \& Niu, G. M. (2017). Application of high-field magnetic resonance imaging in Parkinson's disease. Experimental and Therapeutic Medicine, 13(5), 1665-1670. https://doi.org/10.3892/etm.2016.3551

Rolheiser, T. M., Fulton, H. G., Good, K. P., Fisk, J. D., McKelvey, J. R., Scherfler, C., ... Robertson, H. A. (2011). Diffusion tensor imaging and olfactory identification testing in earlystage Parkinson's disease. Journal of Neurology, 258(7), 1254-1260. https://doi.org/10.1007/s00415-011-5915-2

Scheperjans, F., Aho, V., Pereira, P. A. B., Koskinen, K., Paulin, L., Pekkonen, E., ... Auvinen, P. (2015). Gut microbiota are related to Parkinson's disease and clinical phenotype. Movement Disorders, 30(3), 350-358. https://doi.org/10.1002/mds.26069

Takahashi, H., Watanabe, Y., Tanaka, H., Mihara, M., Mochizuki, H., Liu, T., ... Tomiyama, N. (2018). Quantifying changes in nigrosomes using quantitative susceptibility mapping and neuromelanin imaging for the diagnosis of early-stage Parkinson's disease. The British Journal of Radiology, 20180037. https://doi.org/10.1259/bjr.20180037

Unger, M. M., Spiegel, J., Dillmann, K. U., Grundmann, D., Philippeit, H., Bürmann, J., ... Schäfer, K. H. (2016). Short chain fatty acids and gut microbiota differ between patients with Parkinson's disease and age-matched controls. Parkinsonism and Related Disorders, 32, 6672. https://doi.org/10.1016/j.parkreldis.2016.08.019

Uribe, C., Segura, B., Baggio, H. C., Abos, A., Garcia-Diaz, A. I., Campabadal, A., ... Junque, C. (2018). Gray/White matter contrast in Parkinson's disease. Frontiers in Aging Neuroscience, 10(MAR), 1-8. https://doi.org/10.3389/fnagi.2018.00089

Versace, V., Langthaler, P. B., Sebastianelli, L., Höller, Y., Brigo, F., Orioli, A., ... Nardone, R. 
(2017). Impaired cholinergic transmission in patients with Parkinson's disease and olfactory dysfunction. Journal of the Neurological Sciences, 377, 55-61.

https://doi.org/10.1016/j.jns.2017.03.049

Wenzel, F., Meyer, C., Stehle, T., Peters, J., Siemonsen, S., Thaler, C., \& Zagorchev, L. (2018). Rapid fully automatic segmentation of subcortical brain structures by shape-constrained surface adaptation. Medical Image Analysis, 46, 146-161. https://doi.org/10.1016/j.media.2018.03.001

YuanYuan, L. K. L. Z. L. Z. F. D. S. C. J. L. (2017). Predictive markers for early conversion of iRBD to neurodegenerative synucleinopathy diseases. Neurology, 88, 1493-1500. https://doi.org/10.1212/WNL.0000000000003838

Yuvaraj, R., \& Murugappan, M. (2016). Hemispheric asymmetry non-linear analysis of EEG during emotional responses from idiopathic Parkinson's disease patients. Cognitive Neurodynamics, 10(3), 225-234. https://doi.org/10.1007/s11571-016-9375-3

Yuvaraj, R., Murugappan, M., Acharya, U. R., Adeli, H., Ibrahim, N. M., \& Mesquita, E. (2016). Brain functional connectivity patterns for emotional state classification in Parkinson's disease patients without dementia. Behavioural Brain Research, 298, 248-260. https://doi.org/10.1016/j.bbr.2015.10.036

Yuvaraj, R., Murugappan, M., Mohamed Ibrahim, N., Sundaraj, K., Omar, M. I., Mohamad, K., \& Palaniappan, R. (2014). Detection of emotions in Parkinson's disease using higher order spectral features from brain's electrical activity. Biomedical Signal Processing and Control, 14(1), 108-116. https://doi.org/10.1016/j.bspc.2014.07.005

Yuvaraj, R., Murugappan, M., Omar, M. I., Ibrahim, N. M., Sundaraj, K., Mohamad, K., \& Satiyan, M. (2014). Emotion processing in Parkinson's disease: An EEG spectral power study.

International Journal of Neuroscience, 124(7), 491-502. https://doi.org/10.3109/00207454.2013.860527

Yuvaraj, R., Rajendra Acharya, U., \& Hagiwara, Y. (2018). A novel Parkinson's Disease Diagnosis Index using higher-order spectra features in EEG signals. Neural Computing and Applications, 30(4), 1225-1235. https://doi.org/10.1007/s00521-016-2756-z

Zanigni, S., Calandra-Buonaura, G., Manners, D. N., Testa, C., Gibertoni, D., Evangelisti, S., ... Tonon, C. (2016). Accuracy of MR markers for differentiating Progressive Supranuclear Palsy from Parkinson's disease. NeuroImage: Clinical, 11, 736-742. https://doi.org/10.1016/j.nicl.2016.05.016

Ziegler, D. A., Wonderlick, J. S., Ashourian, P., Hansen, L. A., Young, J. C., Murphy, A. J., ... Corkin, S. (2013). Substantia nigra volume loss before basal forebrain degeneration in early parkinson disease. JAMA Neurology, 70(2), 241-247.

https://doi.org/10.1001/jamaneurol.2013.597

Table 1 Contributions of the main articles of MRI and Early Parkinson disease

\begin{tabular}{|c|c|c|c|c|c|c|c|c|c|}
\hline \multirow[t]{2}{*}{ Author } & \multirow[t]{2}{*}{ Year } & \multirow[t]{2}{*}{ Title } & \multirow[t]{2}{*}{ Objective } & \multirow{2}{*}{$\begin{array}{l}\text { Methodology } \\
\begin{array}{l}\text { Recruitment } \\
\text { patients }\end{array}\end{array}$} & \multicolumn{2}{|c|}{ Population } & \multicolumn{3}{|l|}{ MRI } \\
\hline & & & & & $\mathbf{N}$ & Age & Protocols & Resonator & Zone of brain \\
\hline $\begin{array}{l}\text { (Amoroso } \\
\text { et al., 2018) }\end{array}$ & 2018 & $\begin{array}{l}\text { Complex networks } \\
\text { reveal early MRI } \\
\text { markers of Parkinson's } \\
\text { disease } \\
\end{array}$ & $\begin{array}{l}\text { Propose a novel approach } \\
\text { based on complex networks } \\
\text { for accurate early diagnoses } \\
\text { using magnetic resonance } \\
\text { imaging data }\end{array}$ & Imaging data & 374 PD & N/A & T1WI & $3 \mathrm{~T}$ & $\begin{array}{l}\text { Brain regions mostly affected by the } \\
\text { disease }\end{array}$ \\
\hline $\begin{array}{l}\text { (Wenzel et } \\
\text { al., 2018) }\end{array}$ & 2018 & $\begin{array}{lr}\text { Rapid fully automatic } \\
\text { segmentation of } \\
\text { subcortical brain } \\
\text { structures } \\
\text { shape-constrained } \\
\text { surface adaptation }\end{array}$ & $\begin{array}{l}\text { Present a novel approach for } \\
\text { the rapid segmentation of } \\
\text { clinically relevant subcortical } \\
\text { brain structures in TI-weight } \\
\text { MRI by utilizing a shape- } \\
\text { constrained deformable } \\
\text { surface model }\end{array}$ & Imaging data & 96 & N/A & T1Wi & $3 \mathrm{~T}$ & $\begin{array}{llll}\begin{array}{l}\text { clinically } \\
\text { structures }\end{array} & \text { relevant } & \text { subcortical brain } \\
\end{array}$ \\
\hline
\end{tabular}




\begin{tabular}{|c|c|c|c|c|c|c|c|c|c|}
\hline $\begin{array}{l}\text { (Li et al., } \\
2018)\end{array}$ & 2018 & $\begin{array}{l}\text { Patterns of grey matter } \\
\text { loss associated with } \\
\text { motor subscores in } \\
\text { early } \\
\text { Parkinson's disease }\end{array}$ & $\begin{array}{l}\text { Research associations } \\
\text { between motor subscores and } \\
\text { grey matter at voxel level. }\end{array}$ & $\begin{array}{l}\text { Neurologist } \\
\text { criteria }\end{array}$ & 117 & 62.12 & T1WI structural & N/A & Grey matter intensity \\
\hline $\begin{array}{l}\text { (Takahashi } \\
\text { et al., 2018) }\end{array}$ & 2018 & $\begin{array}{l}\text { Quantifying changes in } \\
\text { nigrosomes using } \\
\text { quantitative } \\
\text { susceptibility mapping } \\
\text { and neuromelaning } \\
\text { imaging for the } \\
\text { diagnosis for early- } \\
\text { stage Parkinson's } \\
\text { disease }\end{array}$ & $\begin{array}{l}\text { Quantify nigral changes with } \\
\text { a focus on their spatial } \\
\text { variation within substantia } \\
\text { nigra pars compact for } \\
\text { diagnosis early-stage } \\
\text { Parkinson's disease }\end{array}$ & $\begin{array}{l}\text { Neurologist } \\
\text { criteria }\end{array}$ & $\begin{array}{l}18(10 \mathrm{M}, \\
8 \mathrm{~W})\end{array}$ & $\begin{array}{l}71.21- \\
69.4\end{array}$ & $\begin{array}{l}\text { T1WI fast spin-echo, } \\
\text { TIWI magnetization- } \\
\text { prepared rapid } \\
\text { acquisition, T2WI fast } \\
\text { spin echo }\end{array}$ & $3 \mathrm{~T}$ & Whole substantia nigral pars compact \\
\hline $\begin{array}{l}\text { (Qiao et al., } \\
\text { 2017) }\end{array}$ & 2017 & $\begin{array}{l}\text { Application of high- } \\
\text { field } \quad \text { magnetic } \\
\text { resonance imaging in } \\
\text { Parkinson's disease }\end{array}$ & $\begin{array}{l}\text { Observe structural changes of } \\
\text { the extracorticospinal tract in } \\
\text { Parkinson's disease. }\end{array}$ & $\begin{array}{l}\text { Neurologist } \\
\text { criteria }\end{array}$ & $12 \mathrm{M} 18 \mathrm{~W}$ & $54-78$ & $\begin{array}{l}\text { T2WI, PROPELLER, } \\
\text { DWI, T1WI }\end{array}$ & $3 \mathrm{~T}$ & $\begin{array}{l}\text { Structural changes of } \\
\text { extracorticaspinal tract }\end{array}$ \\
\hline $\begin{array}{l}\text { (Zanigni et } \\
\text { al., 2016) }\end{array}$ & 2016 & $\begin{array}{lr}\begin{array}{l}\text { Accuracy of } \\
\text { markers }\end{array} & \begin{array}{r}\text { MR } \\
\text { differentiating }\end{array} \\
\text { Progressive } & \\
\text { Supranuclear } & \end{array}$ & $\begin{array}{l}\text { Compare the diagnostic } \\
\text { accuracy of quantitative } \\
\text { morphometric, volumetric } \\
\text { and DTI metrics for } \\
\text { differentiating progressive } \\
\text { supranuclear r palsy } \\
\text { Richardson's syndrome and } \\
\text { Parkinson's disease. }\end{array}$ & $\begin{array}{l}\text { Neurologist } \\
\text { criteria }\end{array}$ & $\begin{array}{l}19 \text { (PSP) and } \\
43 \mathrm{PD}\end{array}$ & $\begin{array}{l}78 \\
\text { PSP } \\
\text { and } \\
64.7 \\
\text { PD }\end{array}$ & $\begin{array}{l}\text { FLAIR T2WI, T1WI } \\
\text { fast spoiled gradient- } \\
\text { echo, DTI }\end{array}$ & $1.5 \mathrm{~T}, 3 \mathrm{~T}$ & $\begin{array}{l}\text { Brainstem and cerebellar penductes } \\
\text { morphometric. Volumetric analysis of } \\
\text { brain deep grey matter, infratentorial } \\
\text { structures and volumetric analysis }\end{array}$ \\
\hline $\begin{array}{l}\text { (Canu et al., } \\
2015 \text { ) }\end{array}$ & 2015 & $\begin{array}{l}\text { Brain Structural and } \\
\text { Functional } \\
\text { Connectivity in } \\
\text { Parkinson's Disease } \\
\text { With Freezing of Gait }\end{array}$ & $\begin{array}{l}\text { Use multimodal approach to } \\
\text { assess brain structural } \\
\text { pathways and resting state } \\
\text { functional connectivities with } \\
\text { Parkinson's disease. }\end{array}$ & $\begin{array}{l}\text { Neurologist } \\
\text { criteria }\end{array}$ & $\begin{array}{l}23 \text { PD and } \\
36 \mathrm{HC}\end{array}$ & N/A & T2 FLAIR, T1WI & $\begin{array}{l}3 \mathrm{~T} \text { MRI } \\
\text { and Fmri }\end{array}$ & $\begin{array}{l}\text { Grey matter (intracranial volume) and } \\
\text { white matter structures }\end{array}$ \\
\hline $\begin{array}{l}\text { (Mak et al., } \\
\text { 2015) }\end{array}$ & 2015 & $\begin{array}{lr}\begin{array}{l}\text { Baseline } \\
\text { longitudinal }\end{array} \text { and } \\
\text { matter } \\
\text { changes in newly } \\
\text { diagnosed } \\
\text { disease: ICICLinson's } \\
\text { study }\end{array}$ & $\begin{array}{l}\begin{array}{l}\text { Determining structural } \\
\text { imaging }\end{array} \\
\text { associated with prodromal } \\
\text { Parkinson's disease dementia } \\
\text { may allow for the earlier } \\
\text { identification of those at risk, } \\
\text { and allow for targeted modify } \\
\text { therapies. }\end{array}$ & $\begin{array}{l}\text { Neurologist } \\
\text { criteria }\end{array}$ & $128 \mathrm{PD}$ & N/A & T1WI & $3 \mathrm{~T}$ & $\begin{array}{l}\text { Widespread cortical thinning (frontal and } \\
\text { temporal, parietal) }\end{array}$ \\
\hline $\begin{array}{l}\text { (Potgieser } \\
\text { et al., 2014) }\end{array}$ & 2014 & $\begin{array}{lr}\text { Anterior } & \text { Temporal } \\
\text { Atrophy r and } & \text { and } \\
\text { Posterior } & \text { Progression } \\
\text { in Patients with } \\
\text { Parkinson's Disease }\end{array}$ & $\begin{array}{l}\text { Give the change of symptoms } \\
\text { over time, a concurrent } \\
\text { increase in regional atrophy } \\
\text { may further be assumed to } \\
\text { reflect the dynamics process } \\
\text { of disease progression. }\end{array}$ & $\begin{array}{l}\text { Neurologist } \\
\text { criteria }\end{array}$ & $77 \mathrm{Pd} 87 \mathrm{HC}$ & N/A & TIWI & $3 \mathrm{~T}$ & $\begin{array}{l}\text { Cortical atrophy in relation with disease } \\
\text { progression }\end{array}$ \\
\hline $\begin{array}{l}\text { (Chen et al., } \\
\text { 2014) }\end{array}$ & 2014 & $\begin{array}{l}\text { Simultaneous imaging } \\
\text { of locus coeruleus and } \\
\text { substantia nigra with a } \\
\text { quantitative } \\
\text { neuromelanin MRI } \\
\text { approach }\end{array}$ & $\begin{array}{l}\text { Two gradient echo sequences } \\
\text { with magnetization transfer } \\
\text { contrast preparation pulse } \\
\text { were develop to } \\
\text { simultaneously image the } \\
\text { locus coeruleus and } \\
\text { substantia nigra. }\end{array}$ & N/A & $3 \mathrm{~F}$ and $3 \mathrm{M}$ & $20-50$ & & $\begin{array}{l}\text { 3T NM- } \\
\text { MRI }\end{array}$ & $\begin{array}{l}\text { Neuromelanin in the brainstem, locus } \\
\text { coeruleus, substantia nigra }\end{array}$ \\
\hline $\begin{array}{l}\text { (Lee et al., } \\
\text { 2014) }\end{array}$ & 2014 & $\begin{array}{l}\text { Subcortical grey matter } \\
\text { changes in untreated, } \\
\text { early stage Parkinson's } \\
\text { disease without } \\
\text { dementia }\end{array}$ & $\begin{array}{l}\text { Determine whether focal } \\
\text { cortical or subcortical grey } \\
\text { matter changes may be } \\
\text { present from the early } \\
\text { Parkinson's disease stage. }\end{array}$ & $\begin{array}{l}\text { Neurologist } \\
\text { criteria }\end{array}$ & $\begin{array}{l}40 \text { EPD, } 59 \\
\mathrm{HC}\end{array}$ & N/A & & $3 \mathrm{~T}$ & $\begin{array}{l}\text { Evaluate cortical grey matter and } \\
\text { subcortical grey matter structure }\end{array}$ \\
\hline $\begin{array}{l}\text { (Kim et al., } \\
\text { 2014) }\end{array}$ & 2014 & $\begin{array}{l}\text { Topographic pattern of } \\
\text { cortical thinning with } \\
\text { consideration of motor } \\
\text { laterality in Parkinson } \\
\text { disease }\end{array}$ & $\begin{array}{l}\text { Identify whether one sided } \\
\text { symptom dominance has an } \\
\text { influence on cortical thinning } \\
\text { patterns in early stage non- } \\
\text { demented Parkinson's } \\
\text { disease patients form cortical } \\
\text { thickness analysis and } \\
\text { cortical patterns are } \\
\text { associated with motor } \\
\text { functions. }\end{array}$ & $\begin{array}{l}\text { Neurologist } \\
\text { criteria }\end{array}$ & $42 \mathrm{PD} 22 \mathrm{HC}$ & N/A & T1WI & $3 \mathrm{~T}$ & Cortical thickness \\
\hline $\begin{array}{l}\text { (Cerasa et } \\
\text { al., 2013) }\end{array}$ & 2013 & $\begin{array}{l}\text { Age at onset influences } \\
\text { neurodegenerative } \\
\text { processes underlying } \\
\text { PD } \\
\text { with levodopa-induced } \\
\text { dyskinesias }\end{array}$ & $\begin{array}{l}\text { Demonstrated that } \\
\text { Parkinson's disease patients } \\
\text { with levodopa-induced } \\
\text { dyskinease are characterized } \\
\text { by neuroanatomical and } \\
\text { functional changes involving } \\
\text { the profrontal cortex. }\end{array}$ & $\begin{array}{l}\text { Neurologist } \\
\text { criteria }\end{array}$ & $115 \mathrm{PD}$ & 50 & T1WI & $1.5 \mathrm{~T}$ & $\begin{array}{l}\text { Whole brain voxel-wise of grey matter } \\
\text { and cortical thickness }\end{array}$ \\
\hline $\begin{array}{l}\text { (García- } \\
\text { Lorenzo et } \\
\text { al., 2013) }\end{array}$ & 2013 & $\begin{array}{l}\text { The } \\
\text { coeruleus/subcoeruleus } \\
\text { complex in rapid } \\
\text { eye movement sleep } \\
\text { behavior disorders in } \\
\text { Parkinson's disease }\end{array}$ & $\begin{array}{l}\text { Study the integrity of the } \\
\text { locus coeruleus/subcoeruleus } \\
\text { complex in patients with } \\
\text { Parkinson's disease using } \\
\text { combined neuromelaning- } \\
\text { sensitive, structural and } \\
\text { diffusion magnetic resonance } \\
\text { image approaches. }\end{array}$ & $\begin{array}{l}\text { Neurologist } \\
\text { criteria }\end{array}$ & $\begin{array}{l}24 \\
\text { (REM) } \\
19 \text { (NOREM) }\end{array}$ & $\begin{array}{l}\text { PD } \\
18-75 \\
\text { HC } 22\end{array}$ & DT1, T1WI, DTI & $\begin{array}{l}\text { 3T NM- } \\
\text { MRI }\end{array}$ & $\begin{array}{l}\text { Neuromelanin sensitive og the locus } \\
\text { coeruleus and subcoeruleus }\end{array}$ \\
\hline $\begin{array}{l}\text { (Gallagher } \\
\text { et al., 2013) }\end{array}$ & 2013 & $\begin{array}{l}\text { White Matter } \\
\text { Microstructural } \\
\text { Integrity and Executive } \\
\text { Function in Parkinson's } \\
\text { disease }\end{array}$ & $\begin{array}{l}\text { Research the degree to which } \\
\text { diffusion tensor magnetic } \\
\text { resonance imaging are related } \\
\text { to executive function in } \\
\text { Parkinson's disease. }\end{array}$ & $\begin{array}{l}\text { Neurologist } \\
\text { criteria }\end{array}$ & $15 \mathrm{PD} 15 \mathrm{HC}$ & N/A & DTI, T1WI & $3 \mathrm{~T}$ & $\begin{array}{l}\text { White matter microstructural } \\
\text { abnormalities }\end{array}$ \\
\hline $\begin{array}{l}\text { (Ziegler et } \\
\text { al., 2013) }\end{array}$ & 2012 & $\begin{array}{l}\text { Substantia Nigra } \\
\text { Volume Loss Before } \\
\text { BasalForebrain } \\
\text { Degeneration in Early } \\
\text { Parkinson Disease }\end{array}$ & $\begin{array}{l}\text { Test the hypothesis that } \\
\text { degeneration of the substantia } \\
\text { nigra pars compact precedes } \\
\text { that of cholinergic basal } \\
\text { forebrain in Parkinson's } \\
\text { disease. }\end{array}$ & $\begin{array}{l}\text { Neurologist } \\
\text { criteria }\end{array}$ & $29 \mathrm{PD} 27 \mathrm{HC}$ & $\begin{array}{l}65.3- \\
63.7\end{array}$ & $\begin{array}{l}\text { T1WI, , } 3 \mathrm{D} \\
\text { FLAIR }\end{array}$ & $3 \mathrm{~T}$ & $\begin{array}{l}\text { Substantia nigra create a weighted mean } \\
\text { of the multiple echoes, yielding a single } \\
\text { volume., visualize the basal forebrain. }\end{array}$ \\
\hline
\end{tabular}




\begin{tabular}{|c|c|c|c|c|c|c|c|c|c|}
\hline $\begin{array}{l}\text { (Agosta et } \\
\text { al., 2013) }\end{array}$ & 2012 & $\begin{array}{l}\text { The Topography of } \\
\text { Brain Damage at } \\
\text { Different } \\
\text { Stages of Parkinson's } \\
\text { Disease }\end{array}$ & $\begin{array}{l}\text { Research gray matter and } \\
\text { white matter damage at } \\
\text { different clinical stages of } \\
\text { Parkinson's disease to } \\
\text { differentiate the trajectories } \\
\text { of tissue injury in this } \\
\text { condition. }\end{array}$ & $\begin{array}{l}\text { Neurologist } \\
\text { criteria }\end{array}$ & 89 PD $42 \mathrm{HC}$ & N/A & $\begin{array}{lr}\text { T1-weighted } & \\
\text { magnetization } & \\
\text { prepared rapid } \\
\text { acquisition } & \text { gradient } \\
\text { echo } & \\
\end{array}$ & $1.5 \mathrm{~T}$ & White matter and grey matter \\
\hline $\begin{array}{l}\text { (Rolheiser } \\
\text { et al., 2011) }\end{array}$ & 2011 & $\begin{array}{l}\text { Diffusion tensor } \\
\text { imaging and olfactory } \\
\text { identification testing } \\
\text { in early-stage } \\
\text { Parkinson's disease }\end{array}$ & $\begin{array}{l}\text { Compared } \\
\text { newly diagnosed Parkinson's } \\
\text { disease patients with a } \\
\text { matched grou using both } \\
\text { control group } \\
\text { olfactory testing and } \\
\text { diffusion } \\
\text { tensor imaging of the } \\
\text { substantia nigra and anterior } \\
\text { olfactory } \\
\text { structures }\end{array}$ & $\begin{array}{l}\text { Neurologist } \\
\text { criteria }\end{array}$ & $8 \mathrm{M}, 6 \mathrm{~F}$ & $50-64$ & T1WI, T2WI & $1.5 \mathrm{~T}$ & $\begin{array}{l}\text { The olfactory tract and the substantia } \\
\text { nigra }\end{array}$ \\
\hline $\begin{array}{l}\text { (Moessnang } \\
\text { et al., 2011) }\end{array}$ & 2010 & $\begin{array}{l}\text { Altered Activation } \\
\text { Patterns within the } \\
\text { Olfactory Network in } \\
\text { Parkinson's Disease }\end{array}$ & $\begin{array}{l}\text { Obtain in-depth insight into } \\
\text { olfactory network } \\
\text { dysfunction in Parkinson's } \\
\text { disease patients. }\end{array}$ & $\begin{array}{l}\text { Neurologist } \\
\text { criteria }\end{array}$ & $\begin{array}{ll}16 & (8 \\
8 \mathrm{M}) & \mathrm{W},\end{array}$ & $\begin{array}{l}58.4- \\
57.4\end{array}$ & fMRI T2WI, DTI & $3 \mathrm{~T}$ & $\begin{array}{l}\text { For each hemisphere. Mesolimbic } \\
\text { olfactory structures encompass the } \\
\text { piriform cortex, amygdala, para } \\
\text { hippocampal cortex, hippocampus }\end{array}$ \\
\hline $\begin{array}{ll}\text { (Hutchinson } \\
\& & \text { Raff, } \\
2008) & \end{array}$ & 2008 & $\begin{array}{l}\text { Detection of } \\
\text { Parkinson's Disease by } \\
\text { MRI: } \\
\text { Spin-Lattice } \\
\text { Distribution Imaging }\end{array}$ & $\begin{array}{l}\text { Develop an advance MRI } \\
\text { technique for detecting } \\
\text { Parkinson disease which } \\
\text { depends on an images from } \\
\text { two inversion recovery } \\
\text { sequence }\end{array}$ & $\begin{array}{l}\text { Neurologist } \\
\text { criteria }\end{array}$ & $12 \mathrm{PD} 12 \mathrm{HC}$ & $\begin{array}{l}61.4 \\
\text { and } \\
59.2\end{array}$ & $\begin{array}{l}\text { Gray matter and white } \\
\text { matter }\end{array}$ & $1.5 \mathrm{~T}$ & $\begin{array}{l}\text { Measure of disease severity in substantia } \\
\text { nigra }\end{array}$ \\
\hline
\end{tabular}

Table 2 Contributions of the main articles of EEG and Early Parkinson disease

\begin{tabular}{|c|c|c|c|c|c|c|c|c|c|}
\hline \multirow[t]{2}{*}{ Author } & \multirow[t]{2}{*}{ Year } & \multirow[t]{2}{*}{ Title } & \multirow[t]{2}{*}{ Objective } & \multicolumn{3}{|c|}{ Methodology } & \multicolumn{2}{|c|}{ Population } & \multirow[t]{2}{*}{ Results } \\
\hline & & & & $\begin{array}{l}\text { Recruitme } \\
\text { nt patients }\end{array}$ & $\begin{array}{l}\text { Non- } \\
\text { motor } \\
\text { sympto } \\
\text { m }\end{array}$ & Type of test & $\mathbf{N}$ & Age & \\
\hline \multicolumn{10}{|c|}{ Group 1: Cognitive } \\
\hline $\begin{array}{l}\text { (Rajamanickam } \\
\text { Yuvaraj, } \\
\text { Rajendra } \\
\text { Acharya, \& } \\
\text { Hagiwara, } \\
\text { 2018) }\end{array}$ & 2016 & $\begin{array}{l}\text { A novel } \\
\text { Parkinson's } \\
\text { disease } \\
\text { diagnosis } \\
\text { index using } \\
\text { higher-order } \\
\text { spectra in } \\
\text { features in } \\
\text { EEG signals }\end{array}$ & $\begin{array}{l}\begin{array}{l}\text { To explore } \\
\text { application } \\
\text { higher-order } \\
\text { spectra }\end{array} \\
\text { automated for } \\
\text { diagnosis of } \\
\text { Parkinson's disease } \\
\text { using } \\
\begin{array}{l}\text { electroencephalogr } \\
\text { aphy signals }\end{array}\end{array}$ & $\begin{array}{l}\text { Neurologist } \\
\text { criteria }\end{array}$ & cognitive & $\begin{array}{l}\text { The EEG signals were recorded for } 5 \\
\text { minutes eyes-closed resting state on 14- } \\
\text { channel (AF3, AF4, F3,F4, F5, F6, F7, F8, } \\
\text { T7, T8, P7, P8, O1, and O2) wireless (2.4 } \\
\text { GHz band) Emotiv EPOC neuroheadset at } \\
128 \text { Sampling rate. }\end{array}$ & $20 \mathrm{PD}$ & $\begin{array}{l}\text { from } \\
45 \text { to } \\
65 \\
\text { years }\end{array}$ & $\begin{array}{l}\text { The HOS-based method, proposed by the } \\
\text { authors of this paper, has given the superior } \\
\text { performance compared to all available } \\
\text { modalities. The method yielded an optimum } \\
\text { mean accuracy: } 99.62 \% \text {, sensitivity: } 100 \% \text {, and } \\
\text { specificity: } 99.25 \% \text { using spectrum feature. }\end{array}$ \\
\hline (Oh et al., 2018) & 2018 & $\begin{array}{l}\text { A deep } \\
\text { learning } \\
\text { approach for } \\
\text { Parkinson's } \\
\text { disease } \\
\text { diagnosis } \\
\text { from EEG } \\
\text { signals }\end{array}$ & $\begin{array}{l}\text { To use the } \\
\text { electroencephalogr } \\
\text { aphy signals of } \\
\text { twenty PD and } \\
\text { twenty } \\
\text { employing } \\
\text { convolutional } \\
\text { neural network }\end{array}$ & $\begin{array}{l}\text { Neurologist } \\
\text { criteria }\end{array}$ & cognitive & $\begin{array}{l}\text { An emotive EPOC neuroheadset of } 14 \\
\text { channels were used. The participants were } \\
\text { asked to sit comfortably in a quiet room and } \\
\text { were informed before the recording to } \\
\text { refrain from body movements (e.g., } \\
\text { blinking of eyes) during the recording } \\
\text { session. After the recording, the signals } \\
\text { were segmented into 2-seconds window } \\
\text { length }\end{array}$ & $\begin{array}{lr}20 & \text { PD } \\
\text { and } & 20 \\
\text { HC } & \end{array}$ & $\begin{array}{l}\text { from } \\
45 \text { to } \\
65 \\
\text { years }\end{array}$ & $\begin{array}{l}\text { The evaluation parameters namely the accuracy, } \\
\text { sensitivity and specificity were used. The best } \\
\text { diagnostic performance is achieved with the } \\
\text { learning rate of0.0001. The proposed CNN } \\
\text { model yielded an accuracy of } 88.25 \% \text {, } \\
\text { sensitivity and specificity of } 84.71 \% \text { and } \\
91.77 \% \text { respectively. }\end{array}$ \\
\hline $\begin{array}{l}\text { (Özmüş et al., } \\
\text { 2017) }\end{array}$ & 2017 & $\begin{array}{l}\text { Demonstratio } \\
\mathrm{n} \text { of Early } \\
\text { cognitive } \\
\text { impairment in } \\
\text { Parkinson's } \\
\text { disease with } \\
\text { visual P300 } \\
\text { responses }\end{array}$ & $\begin{array}{l}\text { To research the } \\
\text { brain dynamic of } \\
\text { cognitively normal } \\
\text { PD patients and } \\
\text { healthy elderly } \\
\text { control using event- } \\
\text { related potential } \\
\text { and to evaluate } \\
\text { their relationship } \\
\text { with } \\
\text { neuropsychological } \\
\text { test }\end{array}$ & $\begin{array}{l}\text { Neurologic } \\
\text { al criteria }\end{array}$ & $\begin{array}{l}\text { Cognitiv } \\
\mathrm{e}\end{array}$ & $\begin{array}{l}\text { A classical oddball paradigm was used in } \\
\text { the experiment. The visual stimulus has a } \\
\text { time off } 10 \mathrm{~ms} \mathrm{r} / \mathrm{f} \text { a duration of } 1 \mathrm{sec} \text {. The } \\
\text { participant were asked to mentally count } \\
\text { the target stimuli. }\end{array}$ & $\begin{array}{lr}18 & \text { PD } \\
\text { and } & 18 \\
\text { HC } & \end{array}$ & $\begin{array}{l}\text { from } \\
65 \text { to } \\
68 \\
\text { years }\end{array}$ & $\begin{array}{l}\text { There is a significant difference between the } \\
\text { visual P300 amplitude values of the healthy } \\
\text { control group and PD patient. }\end{array}$ \\
\hline Group 2: Olfact & & & & & & & & & \\
\hline
\end{tabular}




\begin{tabular}{|c|c|c|c|c|c|c|c|c|c|}
\hline $\begin{array}{l}\text { (Iannilli, } \\
\text { Stephan, } \\
\text { Hummel, } \\
\text { Reichmann, \& } \\
\text { Haehner, 2017) }\end{array}$ & 2017 & $\begin{array}{l}\text { Olfactory } \\
\text { impairment in } \\
\text { Parkinson } \\
\text { disease is a } \\
\text { consequence } \\
\text { of a central } \\
\text { system decline }\end{array}$ & $\begin{array}{l}\text { To investigate the } \\
\text { olfactory response } \\
\text { in } 71 \text { subjects, } \\
\text { consisting of } \\
\text { Parkinson's disease } \\
\text { patients, hyposmic } \\
\text { ans anosmic } \\
\text { patients and other } \\
\text { causes, and } \\
\text { normosmic } \\
\text { individuals } \\
\text { searching for } \\
\text { sensitive, distinctic } \\
\text { biomarkers for } \\
\text { which we used } \\
\text { sclap event-related } \\
64 \text { channel } \\
\text { electroenchephalog } \\
\text { raphic and } \\
\text { psychological test. }\end{array}$ & $\begin{array}{l}\text { Neurologist } \\
\text { criteria }\end{array}$ & olfactory & $\begin{array}{l}\text { The odor was applied directly to the nostril } \\
\text { through a } \\
\text { cannula, and the visual stimulation was } \\
\text { implemented by a } \\
\text { screen positioned in front of the subject } \\
\text { which presented a } \\
\text { tracking task that the subject had to perform } \\
\text { using the } \\
\text { computer mouse. The task was important to } \\
\text { keep the vigilance } \\
\text { stable and reduce any muscle contraction or } \\
\text { eye a } \\
\text { movement during the EEG acquisition }\end{array}$ & $\begin{array}{l}871 \\
\text { patients } \\
\text { with PC } \\
\text { hyposmi } \\
\mathrm{c}, \\
\text { normos } \\
\text { mic and } \\
\text { anosmic } \\
\text { patients }\end{array}$ & $\begin{array}{l}\text { from } \\
63 \text { to } \\
65 \\
\text { years }\end{array}$ & $\begin{array}{l}\text { we observed reduction a reduction of olfactory } \\
\text { response in PD patients using a smell } \\
\text { psychological test. }\end{array}$ \\
\hline $\begin{array}{l}\text { (Versace et al., } \\
2017 \text { ) }\end{array}$ & 2017 & $\begin{array}{l}\text { Impaired } \\
\text { cholinergic } \\
\text { transmission } \\
\text { in patients } \\
\text { with } \\
\text { Parkinson's } \\
\text { disease and } \\
\text { olfactory } \\
\text { dysfunction }\end{array}$ & $\begin{array}{l}\text { To asses the } \\
\text { cholinergic } \\
\text { function as measure } \\
\text { by short latency } \\
\text { afferent inhibition } \\
\text { in PD with different } \\
\text { degrees of olfactory } \\
\text { dysfunction }\end{array}$ & $\begin{array}{l}\text { Neurologist } \\
\text { criteria }\end{array}$ & $\begin{array}{l}\text { Olfactor } \\
\text { y }\end{array}$ & $\begin{array}{l}\text { The stimulation of the olfactory system to } \\
\text { elicit the OERPs was achieved by a } \\
\text { computer controlled } \\
\text { Olfactometer (Olfactometer OM2S - } \\
\text { Burghart, Medical Instruments), linked } \\
\text { directly with an electroencephalograph } \\
\text { (Micromed Brain Quick } 32 \mathrm{Ch} \text { ). }\end{array}$ & $31 \mathrm{PD}$ & $\begin{array}{l}70 \\
\text { years }\end{array}$ & $\begin{array}{l}\text { PD patients with severe } \\
\text { olfactory dysfunction (absent OERPs) tend to } \\
\text { exhibit lower values of SAI than the other PD } \\
\text { patients much more often than the other way } \\
\text { around. SAI was significantly reduced in the PD } \\
\text { patients with absent OERPs compared with } \\
\text { those with present but abnormal OERPs }\end{array}$ \\
\hline $\begin{array}{l}\text { (Cozac et al., } \\
2017)\end{array}$ & 2017 & $\begin{array}{l}\text { Among early } \\
\text { non-motor } \\
\text { signs or } \\
\text { Parkinson's } \\
\text { disease, } \\
\text { alteration of } \\
\text { olfaction but } \\
\text { no } \\
\text { electroenceph } \\
\text { alographic } \\
\text { spectrum } \\
\text { correlates with } \\
\text { motor } \\
\text { function }\end{array}$ & $\begin{array}{l}\text { To assess the } \\
\text { function of odor } \\
\text { identification using } \\
\text { olfactory } \\
\text { "Screening } 12 \text { test " } \\
\text { between two } \\
\text { samples } \\
\text { Parkinson's disease } \\
\text { and healthy } \\
\text { controls }\end{array}$ & $\begin{array}{l}\text { Database(s } \\
\text { mell } \\
\text { identificati } \\
\text { on testing) } \\
\text { from the } \\
\text { Hospital of } \\
\text { the } \\
\text { University } \\
\text { of Basel }\end{array}$ & $\begin{array}{l}\text { Olfactor } \\
\text { y }\end{array}$ & $\begin{array}{l}\text { EEG with } 214 \text { active electrodes in each } \\
\text { participant, in relaxed eye-closed. the } \\
\text { olfactory assessment using Sniffin Sticks } \\
\text { Screening } 12 \text { test (odorant, orange, coffe, } \\
\text { and fish) }\end{array}$ & $\begin{array}{lr}54 & \text { PD } \\
\text { and } & 21 \\
\text { HC } & \end{array}$ & $\begin{array}{l}68 \\
\text { years }\end{array}$ & $\begin{array}{l}\text { Odor identification capacity is significantly } \\
\text { lower in PD patients than in HC. The exact } \\
\text { mechanism } \\
\text { of this olfactory decline in PD is not fully } \\
\text { understood. No association between olfaction } \\
\text { and resting } \\
\text { EEG power spectrum. The likely reason for this } \\
\text { fact is that } \\
\text { the neurodegeneration occurs in different } \\
\text { systems simultaneously } \\
\text { but independently, and at a different pace }\end{array}$ \\
\hline \multicolumn{10}{|c|}{ Group 3: Emotional } \\
\hline $\begin{array}{l}\text { (Garrido- } \\
\text { Vásquez, Pell, } \\
\text { Paulmann, } \\
\text { Sehm, \& Kotz, } \\
\text { 2016) }\end{array}$ & 2016 & $\begin{array}{l}\text { Impaired } \\
\text { neuronal } \\
\text { processing of } \\
\text { dynamics } \\
\text { faces in let- } \\
\text { onset } \\
\text { Parkinson's } \\
\text { disease }\end{array}$ & 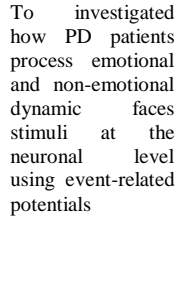 & $\begin{array}{l}\text { Neurologist } \\
\text { criteria }\end{array}$ & $\begin{array}{l}\text { Emotion } \\
\text { al }\end{array}$ & $\begin{array}{l}\text { Produced emotional sentences in a happy, } \\
\text { an angry, and a } \\
\text { neutral tone of voice while showing the } \\
\text { corresponding facial expressions. extended } \\
10-20 \text { system: FP1, FP2, F7, F3, FZ, F4, } \\
\text { F8, FT7, FC3, } \\
\text { FC4, FT8, T7, C3, CZ, C4, T8, CP5, CP6, } \\
\text { P7, PO7, P3, PZ, P4, P8, PO8, O1, and O2. } \\
\text { Acquisition was } \\
\text { carried out with a bandpass between DC } \\
\text { and } 250 \mathrm{~Hz} \text { at a sampling rate of } 500 \mathrm{~Hz} \text {. }\end{array}$ & $\begin{array}{l}24 \quad \mathrm{PD} \\
12 \mathrm{HC}\end{array}$ & N/A & $\begin{array}{l}\text { the LPD group showed } \\
\text { significant face processing deficits compared to } \\
\text { controls. While there were no group differences } \\
\text { in } \\
\text { early, sensory-driven processing (fronto-central } \\
\mathrm{N} 1 \text { and posterior P1), the vertex positive } \\
\text { potential, } \\
\text { which is considered the fronto-central } \\
\text { counterpart of the face-specific posterior N170 } \\
\text { component, had a a a a delayed latency in the } \\
\text { reduced amplitude and delayed } \\
\text { LPD group. }\end{array}$ \\
\hline $\begin{array}{l}\text { R. Yuvaraj \& } \\
\text { Murugappan, } \\
\text { 2016) }\end{array}$ & 2015 & $\begin{array}{l}\text { Hemisphere } \\
\text { asymmetric } \\
\text { non-linear } \\
\text { analysis of } \\
\text { EEG during } \\
\text { emotional } \\
\text { response from } \\
\text { idiopathic } \\
\text { Parkinson's } \\
\text { disease } \\
\text { patients }\end{array}$ & $\begin{array}{l}\text { To investigated } \\
\text { EEG using non- } \\
\text { linear measures } \\
\text { during emotional } \\
\text { processing in PD } \\
\text { patients with } \\
\text { respect to motor } \\
\text { symptoms (most } \\
\text { affected side) }\end{array}$ & $\begin{array}{l}\text { Neurologist } \\
\text { criteria }\end{array}$ & $\begin{array}{l}\text { Emotion } \\
\text { al }\end{array}$ & $\begin{array}{l}\text { The electrodes were arranged at the } \\
\text { scalp sites AF3, AF4, F7, F8, F3, F4, FC5, } \\
\text { FC6, T7, T8, } \\
\text { P7, P8, O1 and O2, according to the 10-20 } \\
\text { system. The emotions namely sadness, } \\
\text { fear, and disgust are elicited using IAPS } \\
\text { and IADS databases }\end{array}$ & $\begin{array}{lr}20 & \text { PD } \\
\text { and } & 20 \\
\text { HC } & \end{array}$ & $\begin{array}{l}\text { from } \\
45 \text { to } \\
65 \\
\text { years }\end{array}$ & $\begin{array}{l}\text { This demonstrates that the connection between } \\
\text { emotions and EEG patterns does not occur in } \\
\text { only } \\
\text { particular band, but it is evident in ALL } \\
\text { frequency bands. The maximum average } \\
\text { accuracy with the combination of ALL } \\
\text { frequency band was } 58.28 \% \pm 3.23 \%, 70.86 \% \\
\pm 1.82 \% \text { and } 83.39 \% \pm 2.04 \% \text { for LPD, RPD } \\
\text { and HC participants, respectively using RBF- } \\
\text { SVM classifier. }\end{array}$ \\
\hline $\begin{array}{l}\text { (R. Yuvaraj et } \\
\text { al., 2016) }\end{array}$ & 2015 & $\begin{array}{l}\text { Brain } \\
\text { functional } \\
\text { connectivity } \\
\text { patterns for } \\
\text { emotional } \\
\text { state } \\
\text { classification } \\
\text { in Parkinson's } \\
\text { disease } \\
\text { patients } \\
\text { without } \\
\text { dementia }\end{array}$ & $\begin{array}{l}\text { To research six } \\
\text { emotions } \\
\text { (happiness, } \\
\text { sadness, fear, } \\
\text { anger, surprise and } \\
\text { disgust) of twenty } \\
\text { non-demented PD } \\
\text { patients and healthy } \\
\text { controls using EEG } \\
\text { brain functional } \\
\text { connectivity }\end{array}$ & $\begin{array}{l}\text { Neurologic } \\
\text { al criteria }\end{array}$ & $\begin{array}{l}\text { Emotion } \\
\text { al }\end{array}$ & $\begin{array}{l}\text { The emotions of sadness, fear, and disgust } \\
\text { were elicited using IAPS and IADS } \\
\text { databases. Center for Emotion and } \\
\text { Attention (CSEA) at the University of } \\
\text { Florida. }\end{array}$ & $\begin{array}{lr}20 & \text { PD } \\
\text { and } & 20 \\
\text { HC } & \end{array}$ & $\begin{array}{l}59.05 \\
- \\
58.10 \\
\text { years }\end{array}$ & $\begin{array}{l}\text { No significant differences among emotional } \\
\text { states are observed in delta and theta frequency } \\
\text { bands of PD patients and HC participants. In } \\
\text { alpha and beta band, there are differences in } \\
\text { connectivity patterns among frontal and } \\
\text { occipital regions in sadness and fear emotions } \\
\text { exhibiting larger correlation than happiness and } \\
\text { surprise in PD patients and HC participants. } \\
\text { Similar results are obtained in the gamma } \\
\text { frequency band, which shows a higher } \\
\text { correlation during sadness, fear and disgust } \\
\text { emotions than happiness and surprise, in the } \\
\text { occipital, parietal and temporal regions. }\end{array}$ \\
\hline
\end{tabular}




\begin{tabular}{|c|c|c|c|c|c|c|c|c|c|}
\hline $\begin{array}{l}\text { R. Yuvaraj, } \\
\text { Murugappan, } \\
\text { Mohamed } \\
\text { Ibrahim, et al., } \\
\text { 2014) }\end{array}$ & 2014 & $\begin{array}{l}\text { Detection of } \\
\text { emotions in } \\
\text { Parkinson } \\
\text { disease using } \\
\text { higher order } \\
\text { spectral } \\
\text { features from } \\
\text { brain's } \\
\text { electrical } \\
\text { activity }\end{array}$ & 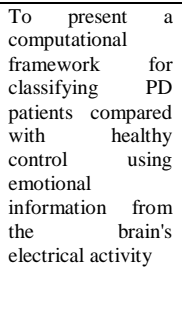 & $\begin{array}{l}\text { Neurologic } \\
\text { al criteria }\end{array}$ & $\begin{array}{l}\text { Emotion } \\
\text { al }\end{array}$ & $\begin{array}{l}\text { Emotion elicitation protocol (happiness, } \\
\text { sadness, dear, anger, surprise and disgust) }\end{array}$ & $\begin{array}{lr}20 & \text { PD } \\
\text { and } & 20 \\
\text { HC } & \end{array}$ & $\begin{array}{l}59 \\
\text { years }\end{array}$ & $\begin{array}{l}\text { Happiness stimuli were recognized easiest than } \\
\text { disgust. Moreover, it can be observed that there } \\
\text { is a decrease in the values of the extracted } \\
\text { features from PD patient's EEG signals as } \\
\text { compared to the healthy controls during emotion } \\
\text { processing. This is due to the dynamic processes } \\
\text { underlying the EEG recording that are less } \\
\text { complex for PD patients than healthy controls. } \\
\text { PD patients achieved less classification } \\
\text { performance for negative emotions, this can in } \\
\text { interpreted as impairment in the brain processing } \\
\text { of emotions, particularly for } \\
\text { negative emotions }\end{array}$ \\
\hline $\begin{array}{l}\text { (R. Yuvaraj, } \\
\text { Murugappan, } \\
\text { Omar, et al., } \\
2014)\end{array}$ & 2014 & $\begin{array}{l}\text { Emotion } \\
\text { progression in } \\
\text { Parkinson } \\
\text { disease: an } \\
\text { EEG power } \\
\text { spectral study }\end{array}$ & $\begin{array}{l}\text { to Examine the } \\
\text { emotion procession } \\
\text { deficits in PD } \\
\text { patients using } \\
\text { electroencephalogr } \\
\text { am (EEG) signal in } \\
\text { response to } \\
\text { multimodal stimuli }\end{array}$ & $\begin{array}{l}\text { Neurologist } \\
\text { criteria }\end{array}$ & $\begin{array}{l}\text { Emotion } \\
\text { al }\end{array}$ & 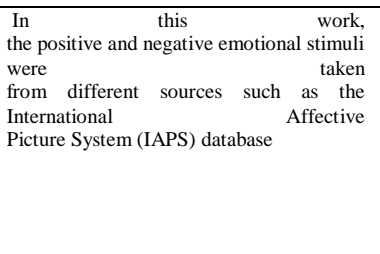 & $\begin{array}{lr}14 & \text { PD } \\
\text { and } & 14 \\
\text { HC } & \end{array}$ & $\begin{array}{l}\text { from } \\
57 \text { to } \\
59 \\
\text { years }\end{array}$ & $\begin{array}{l}\text { The mean values of the relative power spectra in } \\
\text { select frequency bands for PD patients were } \\
\text { lower than in HC across all the regions. The } \\
\text { distribution off the tetha, alpha, betha and } \\
\text { gamma power is lower in PD participants. In } \\
\text { negative emotions the alpha, betha power } \\
\text { decreased in PD than in HC. The results suggest } \\
\text { the possibility of the existence of a distinctive } \\
\text { neurobiological substrate of PD patients during } \\
\text { emotional information processing }\end{array}$ \\
\hline $\begin{array}{lll}\text { (Dietz } & \text { et al., } \\
2013) & & \end{array}$ & 2013 & $\begin{array}{l}\text { The late } \\
\text { positive } \\
\text { potential, } \\
\text { emotional, and } \\
\text { apathy in } \\
\text { Parkinson's } \\
\text { disease }\end{array}$ & $\begin{array}{l}\text { To investigated } \\
\text { emotional } \\
\text { processing in non- } \\
\text { demented } \\
\text { individuals with } \\
\text { Parkinson's disesse } \\
\text { using } \\
\text { electrophysiologica } \\
\text { l measure, the } \\
\text { centro pariental late } \\
\text { positive parietal }\end{array}$ & $\begin{array}{l}\text { Neurologist } \\
\text { criteria }\end{array}$ & $\begin{array}{l}\text { Emotion } \\
\text { al }\end{array}$ & $\begin{array}{l}\text { Seventy-two } \\
\text { pictureswereselectedfromtheInternational } \\
\text { AffectivePicture } \\
\text { System. } 24 \text { unpleasent pictures, } 24 \text { neutral } \\
\text { pictures, } 24 \text { pleasent pictures }\end{array}$ & $\begin{array}{lr}24 & \text { PD } \\
\text { and } & 18 \\
\text { HC } & \end{array}$ & $\begin{array}{l}\text { from } \\
59 \text { to } \\
70 \\
\text { years }\end{array}$ & $\begin{array}{l}\text { Parkinson patients showed reduced defensive } \\
\text { ctivationdur- } \\
\text { ing unpleasant picture viewing as measured by } \\
\text { the amplitude of the centro parietal late positive } \\
\text { potential of the ERP }\end{array}$ \\
\hline \multicolumn{10}{|c|}{ Group 4: sleep disorder } \\
\hline $\begin{array}{l}\text { (Hansen, } \\
\text { Marcussen, } \\
\text { Christensen, } \\
\text { Jennum, \& } \\
\text { Sorensen, 2013) }\end{array}$ & 2013 & $\begin{array}{l}\text { Detection of a } \\
\text { Sleep Disorder } \\
\text { Predicting } \\
\text { Parkinson's } \\
\text { Disease }\end{array}$ & $\begin{array}{l}\text { To develop } \\
\text { supportive methods } \\
\text { for detecting } \\
\text { ideopathic rapid } \\
\text { eye movement } \\
\text { from } \\
\text { electroencephalogr } \\
\text { aphic during REM } \\
\text { sleep }\end{array}$ & $\begin{array}{l}\text { Neurologist } \\
\text { criteria }\end{array}$ & $\begin{array}{l}\text { REM } \\
\text { disorder }\end{array}$ & $\begin{array}{l}\text { The PSG signals used in this study were } \\
\text { retrived from six EEG electrodes placed at } \\
\text { FF3, F4, C3, C4, O1 and } \mathrm{O} 2 \text { with reference } \\
\text { to the far mastoid }\end{array}$ & $\begin{array}{l}10 \\
\text { iRBD } \\
\text { and } 10 \\
\text { healthy } \\
\text { control }\end{array}$ & $\begin{array}{l}59 \\
\text { years }\end{array}$ & $\begin{array}{l}\text { The results from the Smith-Satterthwaite test on } \\
\text { the normalized } \\
\text { data is shown in Table IV. With a } 97.5 \% \\
\text { confidence } \\
\text { two of all features showed significant difference } \\
\text { between } \\
\text { iRBD and control group means, and with } 90 \% \\
\text { confidence } \\
\text { four features were significantly different. }\end{array}$ \\
\hline $\begin{array}{l}\text { (Iwanami, } \\
\text { Miyamoto, } \\
\text { Miyamoto, } \\
\text { Hirata, \& } \\
\text { Takada, 2010) }\end{array}$ & 2010 & $\begin{array}{l}\text { Relevance of } \\
\text { substantia } \\
\text { nigra } \\
\text { hyperechogeni } \\
\text { city and } \\
\text { reduced odor } \\
\text { identification } \\
\text { in idiopathic } \\
\text { REM sleep } \\
\text { behavior } \\
\text { disorder }\end{array}$ & $\begin{array}{l}\text { To reveal a } \\
\text { prodromal } \\
\text { synucleinopathy } \\
\text { in idiopathic REM } \\
\text { sleep behavior } \\
\text { disorder (iRBD). }\end{array}$ & $\begin{array}{l}\text { Neurologist } \\
\text { criteria }\end{array}$ & $\begin{array}{l}\text { Sleep } \\
\text { disorfer } \\
\text { and } \\
\text { olfactory }\end{array}$ & $\begin{array}{l}\text { polisomnography: } \\
\text { chin muscle electrooculography, } \\
\text { (EMG), electrocardiography, and bilateral } \\
\text { EMG of the tibialis } \\
\text { anterior muscles. Olfactory: The Odor } \\
\text { Stick Identification Test for Japanese }\end{array}$ & $34 \mathrm{PD}$ & $\begin{array}{l}64 \\
\text { years }\end{array}$ & $\begin{array}{l}\text { The finding } \text { of an } \\
\text { increased frequency of SN hyperechogenicity in } \\
\text { a subgroup of individuals } \\
\text { with an a priori increased risk for PD supports } \\
\text { the potential } \\
\text { role of SN hyperechogenicity as a risk marker } \\
\text { for PD. The olfactory deficit in PD does not } \\
\text { seem to be related to disease } \\
\text { duration or severity }\end{array}$ \\
\hline
\end{tabular}

Table 3 Contributions of the main articles of microbiome and Early Parkinson disease

\begin{tabular}{|c|c|c|c|c|c|c|c|c|}
\hline \multirow[t]{2}{*}{ Author } & \multirow[t]{2}{*}{ Year } & \multirow[t]{2}{*}{ Title } & \multirow[t]{2}{*}{ Objective } & \multicolumn{2}{|l|}{ Methodology } & \multicolumn{2}{|c|}{ Population } & \multirow[t]{2}{*}{ Results } \\
\hline & & & & $\begin{array}{l}\text { Recruitment } \\
\text { patients }\end{array}$ & Microbiota test & $\mathbf{N}$ & Age & \\
\hline $\begin{array}{l}\text { (F, Hopfner, Künstner A, Müller } \\
\text { SH, Künzel S, Zeuner KE, } \\
\text { Margraf NG, Deuschl G, Baines } \\
\text { JF, 2017) }\end{array}$ & 2017 & $\begin{array}{l}\text { Gut Microbiota in Parkinson Disease } \\
\text { in a northern German cohort }\end{array}$ & $\begin{array}{l}\text { to determine whether } \\
\text { Parkinson } \\
\text { disease is associated } \\
\text { with qualitative or } \\
\text { quantitative changes } \\
\text { in the gut } \\
\text { microbiome. }\end{array}$ & $\begin{array}{l}\text { Neurological } \\
\text { criteria }\end{array}$ & stool samples & $\begin{array}{lr}20 & \text { PD } \\
\text { and } & 29 \\
\text { HC } & \end{array}$ & 69 & $\begin{array}{l}\text { Using a 1000-fold Monte-Carlo simulation } \\
\text { Wilcoxon test the abundance of four } \\
\text { bacterial families differed at first sight } \\
\text { significantly between cases and controls. } \\
\text { ROC Find a predictor of PD to abundacen } \\
\text { of Lactobacillaceae, Enterococcaceae and } \\
\text { Barnesiellaceae }\end{array}$ \\
\hline
\end{tabular}




\begin{tabular}{|c|c|c|c|c|c|c|c|c|}
\hline $\begin{array}{l}\text { (Agata Mulak, Slawomir } \\
\text { Budrewicz, Magdalena Panek- } \\
\text { Jeziorna, Magdalena Koszewicz, } \\
\text { Maria Jasinska, Beata Marczak- } \\
\text { Karpina, Krzysztof Slotwinski, } \\
\text { Ryszard Podemski, 2017) }\end{array}$ & 2017 & 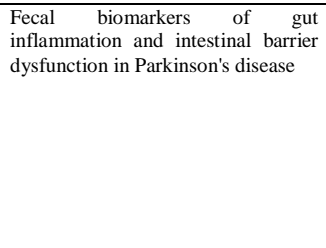 & 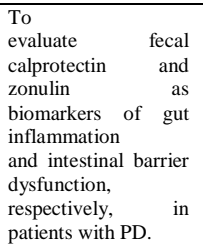 & $\begin{array}{l}\text { Neurological } \\
\text { criteria }\end{array}$ & stool samples & $\begin{array}{lr}10 & \text { PD } \\
\text { and } & 10 \\
\text { HC } & \end{array}$ & 65 & $\begin{array}{l}\text { The increased levels of } \\
\text { calprotectin and zonulin in stool samples } \\
\text { were found in } 60 \% \text { and } 40 \% \text { of PD } \\
\text { patients, respectively. Fecal calprotectin } \\
\text { level was within the normal range } \\
\text { in all the controls, while zonnlin level was } \\
\text { slightly elevated only in on } \\
\text { out of } 10 \text { control subjects. }\end{array}$ \\
\hline (Unger et al., 2016) & 2016 & $\begin{array}{l}\text { Short chain fatty acids and gut } \\
\text { microbiota differ between patients } \\
\text { with } \\
\text { Parkinson's disease and age-matched } \\
\text { controls }\end{array}$ & $\begin{array}{l}\text { To quantify analyzed } \\
\text { SCFA concentrations } \\
\text { (using gas } \\
\text { chromatography) and } \\
\text { microbiota } \\
\text { composition (using } \\
\text { quantitative PCR) in } \\
\text { fecal samples }\end{array}$ & $\begin{array}{l}\text { Neurological } \\
\text { criteria }\end{array}$ & $\begin{array}{l}\text { Fecal samples } \\
\text { immediately frozen } \\
\text { at - 35 C }\end{array}$ & $\begin{array}{lr}34 & \text { PD } \\
\text { and } & 34 \\
\text { HC } & \end{array}$ & 64 & $\begin{array}{lrr}\text { Fecal SCFA concentrations were } \\
\text { significantly reduced in PD patients } \\
\text { compared to controls. The } \\
\text { bacterial phylum Bacteroidetes and the } \\
\text { bacterial family Prevotellaceae were } \\
\text { reduced, } & \text { Enterobacteriaceae } \\
\text { were more abundant in fecal samples from } \\
\text { PD patients compared to matched controls. }\end{array}$ \\
\hline (Scheperjans et al., 2015) & 2015 & $\begin{array}{l}\text { Gut microbiota are related to } \\
\text { Parkinson's disease and clinical } \\
\text { phenotype }\end{array}$ & $\begin{array}{l}\text { To compar the fecal } \\
\text { microbiomes of } 72 \\
\text { PD patients and } 72 \\
\text { control subjects by } \\
\text { pyrosequencing the } \\
\text { V1-V3 regions of the } \\
\text { bacterial } 16 \mathrm{~S} \\
\text { ribosomal RNA gene }\end{array}$ & $\begin{array}{l}\text { Neurological } \\
\text { criteria }\end{array}$ & $\begin{array}{l}\text { fecal samples PCR } \\
\text { amplified and } \\
\text { pyrose- } \\
\text { quenced the V1- } \\
\text { V3 regions of the } \\
\text { bacterial } 16 S \text { ribo- } \\
\text { somal RNA gene } \\
\text { and used these } \\
\text { sequences for } \\
\text { taxonomic } \\
\text { assignment. }\end{array}$ & $\begin{array}{lr}72 & \text { PD } \\
\text { and } & 72 \\
\text { HC } & \end{array}$ & 64 & 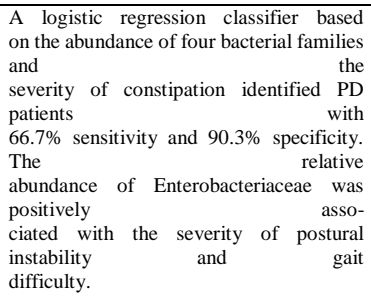 \\
\hline
\end{tabular}

